\title{
Investigating the Causes of the Response of the Thermohaline Circulation to Past and Future Climate Changes
}

\author{
R. J. Stouffer, ${ }^{a}$ J. Yin, ${ }^{b}$ J. M. Gregory, ${ }^{c}$ K. W. Dixon, ${ }^{a}$ M. J. Spelman, ${ }^{a}$ W. Hurlin, ${ }^{a}$ A. J. Weaver, ${ }^{\mathrm{d}}$ \\ M. Eby, ${ }^{\mathrm{d}}$ G. M. Flato, ${ }^{\mathrm{e}}$ H. Hasumi,${ }^{\mathrm{f}}$ A. Hu, ${ }^{\mathrm{g}} \mathrm{J}$. H. Jungclaus, ${ }^{\mathrm{h}}$ I. V. Kamenkovich, ${ }^{\mathrm{i}}$ A. Levermann, ${ }^{\mathrm{j}}$ \\ M. Montoya,${ }^{k}$ S. Murakami, ${ }^{1}$ S. Nawrath,${ }^{j}$ A. Oka, ${ }^{f}$ W. R. Peltier,${ }^{m}$ D. Y. Robitaille, ${ }^{e}$ \\ A. Sokolov, ${ }^{\mathrm{n}}$ G. Vettoretti, ${ }^{\mathrm{m}}$ And S. L. Weber ${ }^{\mathrm{o}}$ \\ ${ }^{a}$ NOAA/Geophysical Fluid Dynamics Laboratory, Princeton, New Jersey \\ ${ }^{\mathrm{b}}$ NOAA/Geophysical Fluid Dynamics Laboratory, and Program in Atmospheric and Oceanic Sciences, Princeton University, \\ Princeton, New Jersey \\ ${ }^{\mathrm{c}}$ Department of Meteorology, University of Reading, Reading, and Hadley Centre for Climate Prediction and Research, Met Office, \\ Exeter, United Kingdom \\ ${ }^{\mathrm{d}}$ School of Earth and Ocean Sciences, University of Victoria, Victoria, British Columbia, Canada \\ ${ }^{\mathrm{e}}$ Canadian Centre for Climate Modelling and Analysis, Victoria, British Columbia, Canada \\ ${ }^{\mathrm{f}}$ Center for Climate System Research, University of Tokyo, Tokyo, Japan \\ ${ }^{\mathrm{g}}$ National Center for Atmospheric Research, Boulder, Colorado \\ ${ }^{\mathrm{h}}$ Max-Planck-Institute for Meteorology, Hamburg, Germany \\ ${ }^{\mathrm{i}}$ University of Washington, Seattle, Washington \\ j Potsdam Institute for Climate Impact Research, Potsdam, Germany \\ ${ }^{\mathrm{k}}$ Department of Astrophysics and Atmospheric Sciences, Universidad Complutense, Madrid, Spain \\ ${ }^{1}$ Meteorological Research Institute, Tsukuba, Japan \\ ${ }^{\mathrm{m}}$ Department of Physics, University of Toronto, Toronto, Ontario, Canada \\ ${ }^{\mathrm{n}}$ Massachussetts Institute of Technology, Cambridge, Massachusetts \\ ${ }^{\circ}$ Royal Netherlands Meteorological Institute, De Bilt, Netherlands
}

(Manuscript received 18 May 2005, in final form 22 September 2005)

\begin{abstract}
The Atlantic thermohaline circulation (THC) is an important part of the earth's climate system. Previous research has shown large uncertainties in simulating future changes in this critical system. The simulated THC response to idealized freshwater perturbations and the associated climate changes have been intercompared as an activity of World Climate Research Program (WCRP) Coupled Model Intercomparison Project/Paleo-Modeling Intercomparison Project (CMIP/PMIP) committees. This intercomparison among models ranging from the earth system models of intermediate complexity (EMICs) to the fully coupled atmosphere-ocean general circulation models (AOGCMs) seeks to document and improve understanding of the causes of the wide variations in the modeled THC response. The robustness of particular simulation features has been evaluated across the model results. In response to $0.1-\mathrm{Sv}\left(1 \mathrm{~Sv} \equiv 10^{6} \mathrm{~m}^{3} \mathrm{~s}^{-1}\right)$ freshwater input in the northern North Atlantic, the multimodel ensemble mean THC weakens by $30 \%$ after $100 \mathrm{yr}$. All models simulate some weakening of the THC, but no model simulates a complete shutdown of the THC. The multimodel ensemble indicates that the surface air temperature could present a complex anomaly pattern with cooling south of Greenland and warming over the Barents and Nordic Seas. The Atlantic ITCZ tends to shift southward. In response to 1.0-Sv freshwater input, the THC switches off rapidly in all model simulations. A large cooling occurs over the North Atlantic. The annual mean Atlantic ITCZ moves into the Southern Hemisphere. Models disagree in terms of the reversibility of the THC after its shutdown. In general, the EMICs and AOGCMs obtain similar THC responses and climate changes with more pronounced and sharper patterns in the AOGCMs.
\end{abstract}

Corresponding author address: Dr. Ronald Stouffer, NOAA/Geophysical Fluid Dynamics Laboratory, Princeton University, Princeton, NJ 08690.

E-mail: ronald.stouffer@noaa.gov 


\section{Introduction}

The importance of the Atlantic thermohaline circulation (THC) to climate and climate change stems from its two unique properties: its large northward heat transport and nonlinear dynamical behavior. Here we define the THC as the part of the ocean circulation that involves warm, saline surface water flowing northward and the cold, dense water flowing southward at depth in the Atlantic basin (Wunsch 2002). The warm, saline surface water flows into high latitudes of the Northern Hemisphere where it is cooled and sinks to depth. These waters then flow southward at depth through the Atlantic Ocean, mainly as a deep western boundary current, until they reach the Southern Ocean where they mix with the rest of the World Ocean waters.

Some past abrupt climate changes are considered to have resulted from rapid reorganizations of the THC (Boyle and Keigwin 1987; Duplessy et al. 1988; Broecker 1997; Clark et al. 2002). Modeling studies indicate that the THC is potentially sensitive to changes in surface buoyancy fluxes induced by anthropogenic climate change (Dixon et al. 1999; Mikolajewicz and Voss 2000; Cubasch et al. 2001; Gregory et al. 2005), and some model simulations have suggested that large changes of the THC are possible in the future (Manabe and Stouffer 1995; Stocker and Schmittner 1997). Severe concerns about the future evolution of this critical system have resulted in detailed investigations of the dynamical behavior of the THC and THC-induced climate changes. Although much work has been done (Manabe and Stouffer 1988, 1995, 1999a,b; Stocker and Wright 1991; Rahmstorf 1995; Schiller et al. 1997; Dixon et al. 1999; Vellinga and Wood 2002; Gregory et al. 2003), the previous research unfortunately points to substantial uncertainties in the model's THC response. For example, the sensitivity of the THC to freshwater addition, the magnitude of the THC-induced cooling, the cooling region, the reversibility of the THC after its collapse, etc., are all highly model dependent. The disagreement among model simulations is a clear indication of the complexity of the THC system. It also reflects limitations in current understanding of how the large-scale climate system operates.

For simulated climate change, all the relevant data are in principle available for analysis and understanding of the model results, yet the reasons for the differences among the models are largely unknown and have not been studied systematically. To address this deficiency and hence reduce the uncertainties in modeling the dynamical behavior of the THC and THC-induced climate change, two sets of coordinated THC experiments were set up as an activity of the Coupled Model Inter- comparison Project (CMIP) of the World Meteorological Organization/World Climate Research Program/ Program on Climate Variability and Predictability (WMO/WCRP/CLIVAR) Working Group on Coupled Models (WGCM; www-pcmdi.llnl.gov/projects/cmip/ index.php). One set of coordinated experiments (socalled water hosing - see below) is also an activity of the Paleo-Modeling Intercomparison Project (PMIP), also part of the WCRP.

The coordinated experiments comprise simulations of a common design being undertaken at institutions worldwide using their own climate models, either coupled atmosphere-ocean general circulation models (AOGCMs) or earth system models of intermediate complexity (EMICs). AOGCMs are the main tools used for climate prediction but require large computing resources, so EMICs are also widely used to study past or future climate changes. Table 1 lists the participating institutions and basic structures of the models used in this study. The purpose of the coordinated experiments is to assess the differences in model responses and investigate the reasons for those differences. By combining representative model simulations in a multimodel ensemble, the robustness of a particular simulation feature can be evaluated. The set of so-called partially coupled experiments allows the role of the surface fluxes in the weakening of the THC when greenhouse gases increase to be investigated (Gregory et al. 2005). In the second set of experiments, the so-called waterhosing simulations, the response of the THC to a specified external source of freshwater and the resulting climate change are studied. This water-hosing experimental design is highly idealized. Its results have implications not only for future climate changes, but also to help understand past climate changes seen in the paleorecord. The implication for increasing understanding of past climate changes encouraged the PMIP to cosupport this second experiment along with CMIP.

This paper focuses on the water-hosing experiments. The purpose is to describe the experimental design (section 2) and document the results obtained so far (sections 3 and 4). It is anticipated that other papers will follow that will explore many of the questions raised by this paper in more detail.

\section{Design of the water-hosing experiments}

The water-hosing experiments study the sensitivity of the THC to an external source of freshwater. In a perturbation experiment, an additional freshwater flux of $0.1 \mathrm{~Sv}\left(1 \mathrm{~Sv} \equiv 10^{6} \mathrm{~m}^{3} \mathrm{~s}^{-1}\right)$ is applied for $100 \mathrm{yr}$ to the northern North Atlantic Ocean. The external water flux is then switched off after model year 100 and the 
integration continues, in order to investigate whether or not the THC recovers its initial strength and the rate of the recovery. A control integration, with no external water flux forcing, runs in parallel to the perturbation integration. The size of the forcing ("hosing") freshwater flux, which is approximately equal to the runoff of the Amazon River, was chosen to be of the order of magnitude predicted for a large $\mathrm{CO}_{2}$-induced climate change. For instance, at $4 \times \mathrm{CO}_{2}$ in the Third Hadley Centre Coupled Ocean-Atmosphere GCM (HadCM3; experiment 2PC of Wood et al. 1999), the increase in water flux from precipitation, evaporation, and river runoff into the Arctic and Atlantic Oceans north of $45^{\circ} \mathrm{N}$ is $0.14 \mathrm{~Sv}$. Similar freshwater flux changes were simulated for the late twenty-first century in a version of the Geophysical Fluid Dynamics Laboratory's (GFDL's) R15 model (Fig. 3 of Dixon et al. 1999). These fluxes are thought to be the dominant terms in the water budget over the next $100 \mathrm{yr}$. The Greenland ice sheet might add about half as much; in the most extreme scenarios considered in the Intergovernmental Panel on Climate Change (IPCC) Third Assessment Report (Church et al. 2001), melting of the ice sheet contributes about $6 \mathrm{~mm} \mathrm{yr}^{-1}$ to global average sea level rise, equivalent to $0.07 \mathrm{~Sv}$. Melting of perennial Arctic sea ice gives a term an order of magnitude smaller; a volume of $2 \times 10^{13} \mathrm{~m}^{3}$ melting in $50 \mathrm{yr}$ yields a flux of $0.01 \mathrm{~Sv}$.

The hosing flux is applied uniformly over the Atlantic between $50^{\circ}$ and $70^{\circ} \mathrm{N}$. This is obviously an idealization, and there will be some sensitivity to the region chosen (Rahmstorf 1996; Gregory et al. 2003). A broad area is chosen so as to ensure that the model-to-model variations in the location of deep convection are likely to be situated under the region of freshening. It also helps solve limitations found in many ocean general circulation models to handle large local water fluxes. These limitations are due to the assumptions used in the model construction (e.g., the so-called rigid lid used to filter the fast waves observed in the ocean) and in the numerical algorithms used to compute advection of water properties. Ocean models are now being constructed that do not suffer from these issues (see Griffies 2004 as one example). However most of the models used here have these limitations, and therefore a large area was chosen for the water-hosing forcing in an attempt to minimize the effect of the numerical issues on the results presented below.

After obtaining the results from the standard waterhosing experiment, some groups performed a second water-hosing experiment. In this experiment, the design is the same as described above except that the rate is 10 times larger, $1.0 \mathrm{~Sv}$, approximately equal to the total global river runoff. This rate is sufficient to shut down the THC in some models over $30 \mathrm{yr}$ or less. A water flux as large as $1.0 \mathrm{~Sv}$ is extremely unlikely under realistic $\mathrm{CO}_{2}$ scenarios, however, this flux is within the range envisaged for events driven by meltwater release during the last glacial era and the deglaciation (Clarke et al. 2003), though not for periods as long as a century. This rate would add about $9 \mathrm{~m}$ of globally averaged sea level over a 100 -yr period. In addition, similar sea level rises have been caused by the massive iceberg discharges from the Laurentide Ice Sheet during the Heinrich events (Calov et al. 2002; Chappell 2002). Over a 1000yr period, these discharges could induce a freshwater flux on the order of $0.1 \mathrm{~Sv}$.

\section{Results}

\section{a. 0.1-Sv water-hosing experiment}

Table 2 shows the data from this experiment used in the following analyses. In the present study, we mainly summarize the simulations in terms of the mean of the model as an ensemble and focus on selected variables (see Table 2). To construct the geographical distribution of the ensemble mean, the models' results are first interpolated to a common $1^{\circ} \times 1^{\circ}$ grid. The mean value at each common point is then calculated and plotted using all available model simulations.

\section{1) The THC Response}

The sensitivity of the THC to external freshwater forcing varies among different climate models (Bryan 1986; Schiller et al. 1997; Manabe and Stouffer 1999a,b). In response to freshwater perturbation, the reduction of the THC intensity is proportional to both the magnitude and duration of the perturbation (Rind et al. 2001). Because of the slow adjustment of the deep ocean, the integrations are transient and not equilibrium responses (Stouffer 2004). Here we define the THC intensity as the maximum meridional overturning streamfunction value in the North Atlantic excluding the surface wind-driven overturning circulation. The THC intensity varies greatly among the control runs of the participating models (Fig. 1). There are large differences in terms of the mean intensity and in the amplitude and period of its multidecadal variations. The model results can be classified into three groups according to the characteristics of the THC in the control runs. The first group includes the GFDL Climate Model version 2.1 (GFDL_CM2.1) GFDL_R30, HadCM3, ECBILT_CLIO, and UToronto models. The THC in these models is vigorous and presents pronounced multidecadal variations. The second group in- 
TABLE 1. Participating institutions and models. Model resolution: lat $\times$ lon and number of levels.

\begin{tabular}{|c|c|c|c|c|}
\hline Model & Institute & Type & Atmospheric model & Oceanic model \\
\hline CCC_CGCM2 & $\begin{array}{l}\text { Canadian Center for Climate } \\
\text { Modelling and Analysis, } \\
\text { Canada }\end{array}$ & AOGCM & $\mathrm{T} 32\left(3.7^{\circ} \times 3.7^{\circ}\right), \mathrm{L} 10$ & MOM1.1, $1.8^{\circ} \times 1.8^{\circ}, \mathrm{L} 29$ \\
\hline CLIMBER_2 & $\begin{array}{l}\text { Potsdam Institute for Climate } \\
\text { Impact Research, Germany }\end{array}$ & EMIC & $\begin{array}{l}10^{\circ} \times 51^{\circ}, \text { L10 (dynamics) } \\
\text { L16 (radiative), vertically } \\
\text { integrated thermodynamics }\end{array}$ & $\begin{array}{l}\text { A zonally averaged model } \\
\text { with three separate basins }\end{array}$ \\
\hline CLIMBER_3 $\alpha$ & $\begin{array}{l}\text { Potsdam Institute for Climate } \\
\text { Impact Research, Germany }\end{array}$ & EMIC & $\begin{array}{l}\text { Same as CLIMBER_2 with } \\
\text { increased resolution of } 7.5^{\circ} \\
\times 22.5^{\circ}\end{array}$ & $\begin{array}{c}\text { MOM3, } 3.75^{\circ} \times 3.75^{\circ}, 24 \\
\text { variably spaced levels }\end{array}$ \\
\hline ECBilt/CLIO & $\begin{array}{l}\text { Royal Netherlands } \\
\text { Meteorological Institute, } \\
\text { Netherlands }\end{array}$ & EMIC & $\begin{array}{l}\text { ECBilt; T21, L3, } \\
\text { quasigeostrophic model } \\
\text { with dynamically computed } \\
\text { correction for the } \\
\text { ageostrophic terms }\end{array}$ & $\begin{array}{l}\text { CLIO, } 3^{\circ} \times 3^{\circ} \text {, variably } \\
\text { spaced levels, free-surface } \\
\text { global general circulation } \\
\text { model }\end{array}$ \\
\hline ECHAM5/MPI-OM & $\begin{array}{l}\text { Max Planck Institute for } \\
\text { Meteorology, Germany }\end{array}$ & AOGCM & T31, L19 & $\begin{array}{l}3^{\circ} \times 3^{\circ} ; \text { the grid has poles } \\
\text { over Greenland and } \\
\text { Antarctica }\end{array}$ \\
\hline GFDL_CM2.1 & $\begin{array}{c}\text { Geophysical Fluid Dynamics } \\
\text { Laboratory, United States }\end{array}$ & AOGCM & $\begin{array}{l}2^{\circ} \times 2.5^{\circ}, \text { L2 } 24 \text {, finite volume } \\
\text { dynamical core }\end{array}$ & $\begin{array}{l}\text { MOM } 4,1^{\circ} \times 1^{\circ} \text { with } \\
\text { enhanced resolution at } \\
\text { Tropics }\left(1 / 3^{\circ} \text { at equator }\right) \text {, } \\
\text { L50, tripolar }\end{array}$ \\
\hline GFDL_R30 & $\begin{array}{l}\text { Geophysical Fluid Dynamics } \\
\text { Laboratory, United States }\end{array}$ & AOGCM & $\mathrm{R} 30\left(2.25^{\circ} \times 3.75^{\circ}\right), \mathrm{L} 14$ & MOM1.1, $2.25^{\circ} \times 1.9^{\circ}, \mathrm{L} 18$ \\
\hline HadCM3 & $\begin{array}{l}\text { Hadley Centre for Climate } \\
\text { Prediction and Research, } \\
\text { United Kingdom }\end{array}$ & AOGCM & $2.5^{\circ} \times 3.75^{\circ}, \mathrm{L} 19$ & Pre-MOM, $1.25^{\circ} \times 1.25^{\circ}, \mathrm{L} 20$ \\
\hline MIROC3.2 & University of Tokyo, Japan & AOGCM & $\mathrm{T} 42, \mathrm{~L} 20$ & $\begin{array}{l}\mathrm{COCO} 3.3 ;\left(0.5^{\circ} \sim 1.4^{\circ}\right) \times \\
1.4^{\circ}, \mathrm{L} 43\end{array}$ \\
\hline MIT_UWash & $\begin{array}{l}\text { Massachusetts Institute of } \\
\text { Technology and University } \\
\text { of Washington, United } \\
\text { States }\end{array}$ & EMIC & $\begin{array}{l}\text { A } 2 \text { D (zonally averaged) } \\
\text { statistical-dynamical model, } \\
7.82^{\circ} \text { in lat, L9 }\end{array}$ & $\begin{array}{l}\mathrm{MOM} 2,4^{\circ} \times 1^{\circ} \sim 3.75^{\circ}, \text { two } \\
\text { rectangular basins, } 3 \mathrm{D} \\
\text { ocean general circulation } \\
\text { model }\end{array}$ \\
\hline MRI_CGCM2.3 & $\begin{array}{l}\text { Meteorological Research } \\
\text { Institute, Japan }\end{array}$ & AOGCM & $\mathrm{T} 42, \mathrm{~L} 30$ & $0.5^{\circ}-2.0^{\circ} \times 2.5^{\circ}, \mathrm{L} 23$ \\
\hline NCAR_CCSM 2.0 & $\begin{array}{l}\text { National Center for } \\
\text { Atmospheric Research, } \\
\text { United States }\end{array}$ & AOGCM & $\begin{array}{l}\mathrm{T} 42\left(\sim 2.8^{\circ} \text { lat } \times 2.8^{\circ} \text { lon }\right) \\
\text { L26, hybrid vertical } \\
\text { coordinate }\end{array}$ & $\begin{array}{l}\text { POP, displaced pole, } 1^{\circ} \times 1^{\circ} \text {, } \\
\quad \text { L40 }\end{array}$ \\
\hline UToronto & $\begin{array}{l}\text { University of Toronto, } \\
\text { Canada }\end{array}$ & AOGCM & $\begin{array}{l}\text { CCM3, T32 }\left(\sim 3.7^{\circ} \times 3.7^{\circ}\right) \\
\quad \text { L18 }\end{array}$ & $\begin{array}{l}\text { NCOM }\left(3^{\circ} \times 3^{\circ}\right) \text { with } \\
\text { enhanced resolution in } \\
\text { Tropics }\left(1.8^{\circ}\right), \text { L25 }\end{array}$ \\
\hline UVic & $\begin{array}{l}\text { University of Victoria, } \\
\text { Canada }\end{array}$ & EMIC & $\begin{array}{l}\text { An energy moisture balance } \\
\text { atmospheric model with } \\
\text { dynamical feedbacks, } 1.8^{\circ} \\
\times 3.6^{\circ}\end{array}$ & $\begin{array}{l}\text { MOM2.2, } 1.8^{\circ} \times 3.6^{\circ}, \text { L19 } \\
\text { unequally spaced }\end{array}$ \\
\hline
\end{tabular}

cludes CCC_CGCM2, ECHAM5/MPI-OM, MIROC3.2, MRI_CGCM2.3, and NCAR_CCSM2.0. In these models, the THC is relatively weak and the amplitude of its multidecadal variations is small. CLIMBER, MIT_UWash and UVic belong to the third group, in which the THC has little variation. As noted in Table 1, the models in this last group do not incorporate an atmospheric component that resolves synoptic variability. Therefore, they do not generate enough "noise" to excite multidecadal oscillations of the THC. The rea- sons why the decadal time-scale variability between the first two groups differs so much, and why the mean THC intensity varies widely among all the models, are not clear. Possible mechanisms for these differences have been suggested in previous research work (Weaver and Sarachik 1991; Delworth et al. 1993; Timmermann et al. 1998; Cheng et al. 2004; Vellinga and $\mathrm{Wu} 2004$ ) and are the possible subject for future investigations.

The THC intensity anomalies (Fig. 2) in the 0.1-Sv 
TABLE 1. Continued.

\begin{tabular}{|c|c|c|c|c|c|c|c|c|}
\hline Model & $\begin{array}{l}\text { Land } \\
\text { model }\end{array}$ & $\begin{array}{l}\text { Sea ice } \\
\text { model }\end{array}$ & $\begin{array}{l}\text { Water } \\
\text { coupling } \\
\text { through }\end{array}$ & $\begin{array}{c}\text { Flux } \\
\text { adjustment }\end{array}$ & $\begin{array}{c}\mathrm{CO}_{2} \\
(\mathrm{ppmv})\end{array}$ & $\begin{array}{c}\text { Solar } \\
\text { constant } \\
\left(\mathrm{W} \mathrm{m}^{-2}\right)\end{array}$ & $\begin{array}{l}\text { Oceanic diffusivity } \\
\qquad\left(\mathrm{m}^{2} \mathrm{~s}^{-1}\right)\end{array}$ & Reference \\
\hline CCC_CGCM2 & $\mathrm{M}, \mathrm{BB}$ & $\mathrm{T}, \mathrm{R}$ & VSF & Heat, water & 330 & 1370 & $\begin{array}{c}\text { GM, along-isopycnal: } 1 \times \\
10^{3} \text {, horizontal: } 1 \times \\
10^{2} \text {, vertical: } 5 \times 10^{-5}\end{array}$ & $\begin{array}{l}\text { Flato and Boer } \\
\text { (2001) }\end{array}$ \\
\hline CLIMBER_2 & $\mathrm{C}$ & $\mathrm{T}, \mathrm{F}$ & VSF & - & 280 & 1365 & $\begin{array}{l}\text { Horizontal: } 1 \sim 2 \times 10^{3} \text {, } \\
\quad \text { vertical: } 0.5 \sim 1.5 \times 10^{-4}\end{array}$ & $\begin{array}{l}\text { Petoukhov et al. } \\
(2000)\end{array}$ \\
\hline CLIMBER_3 $3 \alpha$ & $\mathrm{C}$ & $\mathrm{T}, \mathrm{R}$ & FWF & $\begin{array}{l}\text { Wind anomaly } \\
\text { model }\end{array}$ & 280 & 1365 & GM, vertical: $0.1 \times 10^{-4}$ & $\begin{array}{l}\text { Montoya et al. } \\
\text { (2005) }\end{array}$ \\
\hline ECBilt/CLIO & $\mathrm{B}$ & $\mathrm{T}, \mathrm{R}$ & FWF & $\begin{array}{l}\text { Water (fixed } \\
\text { reduction in } \\
\text { Atlantic } \\
\text { basin) }\end{array}$ & 280 & 1365 & GM & $\begin{array}{l}\text { de Vries and Weber } \\
(2005)\end{array}$ \\
\hline $\begin{array}{l}\text { ECHAM5/ } \\
\text { MPI-OM }\end{array}$ & $\mathrm{C}$ & $\mathrm{T}, \mathrm{R}$ & FWF & - & 280 & 1365 & $\begin{array}{l}\text { GM, isopycnal diffusion } \\
0.1 \sim 1 \times 10^{3} \text {, } \\
\text { background vertical: } \\
0.1 \times 10^{-4}\end{array}$ & $\begin{array}{l}\text { Jungclaus et al. } \\
\text { (2006) }\end{array}$ \\
\hline GFDL_CM2.1 & $\mathrm{C}$ & $\mathrm{T}, \mathrm{R}$ & FWF & - & 286 & 1365 & GM & $\begin{array}{l}\text { Delworth et al. } \\
\text { (2006) }\end{array}$ \\
\hline GFDL_R30 & $\mathrm{B}$ & $\mathrm{T}, \mathrm{F}$ & VSF & Heat, water & 360 & 1365 & $\begin{array}{l}\text { Background horizontal: } \\
4 \times 10^{2} \text {, isopycnal: } \\
1.9 \times 10^{3} \sim 1 \times 10^{3}, \\
\text { horizontal: } 1.2 \times 10^{5}, \\
\text { vertical: } 0.3 \sim 1.0 \times \\
10^{-4}\end{array}$ & $\begin{array}{l}\text { Delworth et al. } \\
\text { (2002) }\end{array}$ \\
\hline HadCM3 & $\mathrm{C}$ & $\mathrm{T}, \mathrm{F}$ & VSF & - & 290 & 1365 & $\begin{array}{l}\text { GM, along isopycnal } \\
\text { diffusion }\end{array}$ & $\begin{array}{l}\text { Gordon et al. } \\
\quad(2000)\end{array}$ \\
\hline MIROC3.2 & $\mathrm{C}$ & $\mathrm{T}, \mathrm{R}$ & FWF & - & 285 & 1366 & $\begin{array}{l}\text { GM thickness: } 3 \times 10^{2} \text {, } \\
\text { background horizontal: } \\
1 \times 10^{2} \text {, background } \\
\text { vertical: } 1 \times 10^{-5} \sim 2.7 \\
\times 10^{-4} \text {, isopycnal: } 1 \times \\
10^{3}\end{array}$ & $\begin{array}{l}\text { K-1 Model } \\
\text { Developers } \\
(2004)\end{array}$ \\
\hline MIT_UWash & M & $\mathrm{T}$ & VSF & $\begin{array}{l}\text { Heat, water, } \\
\text { momentum }\end{array}$ & 280 & 1367 & $\begin{array}{l}\text { GM, isopycnal: } 10^{3} \text {, } \\
\text { horizontal: } 10^{3} \text {, vertical: } \\
5 \times 10^{-5}\end{array}$ & $\begin{array}{l}\text { Kamenkovich et al. } \\
\text { (2002) }\end{array}$ \\
\hline $\begin{array}{l}\text { MRI_- } \\
\text { CGCM2.3 }\end{array}$ & $\mathrm{C}$ & $\mathrm{T}, \mathrm{F}$ & VSF & $\begin{array}{l}\text { Heat, water, } \\
\text { momentum }\end{array}$ & 345 & 1365 & $\begin{array}{l}\text { GM, isopycnal: } 2 \times 10^{3} \\
\quad \text { diapycnal: } 1 \times 10^{-5}\end{array}$ & $\begin{array}{l}\text { Yukimoto and } \\
\text { Noda (2002) }\end{array}$ \\
\hline $\begin{array}{l}\text { NCAR_ } \\
\text { CCSM2.0 }\end{array}$ & $\mathrm{C}$ & $\mathrm{T}, \mathrm{R}$ & VSF & - & 355 & 1367 & $\begin{array}{l}\text { GM along isopycnals, } \\
\text { background vertical: } \\
0.1 \sim 1 \times 10^{-4}\end{array}$ & $\begin{array}{l}\text { Kiehl and Gent } \\
\quad(2004)\end{array}$ \\
\hline UToronto & $\mathrm{M}, \mathrm{BB}$ & $\mathrm{T}, \mathrm{R}$ & VSF & - & 355 & 1365 & GM & $\begin{array}{l}\text { Otto-Bliesner and } \\
\text { Brady (2001) }\end{array}$ \\
\hline UVic & $\mathrm{C}$ & $\mathrm{T}, \mathrm{R}$ & VSF & $\begin{array}{l}\text { Wind anomaly } \\
\text { model }\end{array}$ & 280 & 1368 & $\begin{array}{l}\text { GM, FCT, background: } \\
\text { 0, isopycnal: } 4 \times 10^{2} \text {, } \\
\text { vertical: } 0.3 \sim 1.3 \times \\
10^{-4}\end{array}$ & $\begin{array}{l}\text { Weaver et al. } \\
(2001)\end{array}$ \\
\hline
\end{tabular}

$\mathrm{B}=$ standard bucket scheme.

$\mathrm{BB}=$ modified bucket scheme with spatially varying soil moisture capacity and a surface resistance.

$\mathrm{M}=$ multilayer temperature scheme.

$\mathrm{C}=$ complex land surface scheme.

$\mathrm{T}=$ thermodynamic ice model only.

$\mathrm{R}=$ ice rheology included.

$\mathrm{F}=$ "free drift" dynamics.

$\mathrm{FWF}=$ freshwater flux.

$\mathrm{VSF}=$ virtual salt flux.

$\mathrm{GM}=$ Gent-McWilliams scheme. 
TABLE 2. Comparison items and model data used for the analyses. Numbers denote the following: 1) maximum meridional overturning streamfunction value in North Atlantic (Sv) (control and hosing); 2) SAT time series averaged over $50^{\circ}$ to $70^{\circ} \mathrm{N}$ in $\mathrm{Atlantic}$ (control and hosing); 3) SAT time series at coldest spot over $50^{\circ} \sim 70^{\circ} \mathrm{N}$ in Atlantic [obtained from SAT difference (years $81-100$ ) minus control (century time average)] during hosing; 4) 2D fields (hosing: time average of years 81-100; control: century time average); 4.1) SAT; 4.2) sea level pressure; 4.3) Precipitation; 4.4) $P-E+R$; 4.5) SST; 4.6) SSS; 4.7) sea ice thickness and concentration; 5) 2D oceanic sections depth vs latitude-Atlantic and global (hosing: time average of years 81-100; control: century time average); 5.1 ) potential temperature; 5.2) salinity; 5.3) meridional overturning streamfunction; 6) zonal mean transports by ocean basin (hosing: time average of years 81-100; control: century time average); 6.1) heat; and 6.2) freshwater.

\begin{tabular}{lccccccccccccccccccc}
\hline \hline & 1 & 2 & 3 & 4.1 & 4.2 & 4.3 & 4.4 & 4.5 & 4.6 & 4.7 & 5.1 & 5.2 & 5.3 & 6.1 & 6.2 \\
\hline CCC_CGCM2 & + & + & + & + & + & + & + & + & + & + & + & + & + & + & + \\
CLIMBER_2 & ++ & ++ & ++ & ++ & ++ & ++ & ++ & & & & ++ & ++ & ++ & ++ & ++ \\
CLIMBER_3 $\alpha$ & ++ & ++ & ++ & ++ & ++ & ++ & ++ & ++ & ++ & ++ & ++ & ++ & ++ & ++ & ++ \\
ECBILT_CLIO & + & + & + & + & & + & + & + & + & + & + & + & + & + & + \\
ECHAM5/MPI-OM & + & + & + & + & + & + & + & + & + & + & + & + & + & + & + \\
GFDL_CM2.1 & ++ & ++ & ++ & ++ & ++ & ++ & ++ & ++ & ++ & ++ & ++ & ++ & ++ & ++ & ++ \\
GFDL_R30 & ++ & ++ & ++ & ++ & ++ & ++ & ++ & ++ & ++ & ++ & ++ & ++ & ++ & ++ & ++ \\
HadCM3 & ++ & ++ & ++ & ++ & ++ & ++ & ++ & ++ & ++ & ++ & ++ & ++ & ++ & ++ & ++ \\
MIROC3.2 & + & + & + & + & + & + & & + & + & + & + & + & + & + & + \\
MIT_UWash & ++ & ++ & ++ & & & & & & & & + & + & + & + & + & + \\
MRI_CGCM2.3 & + & + & + & + & + & + & + & + & + & + & + & + & + & + & + \\
NCAR_CCSM2.0 & ++ & + & + & ++ & + & ++ & + & + & + & + & + & + & + & + & + \\
UTOronto & ++ & ++ & ++ & ++ & ++ & ++ & ++ & ++ & ++ & ++ & ++ & ++ & ++ & ++ & ++ \\
UVic & ++ & ++ & ++ & ++ & & ++ & ++ & ++ & ++ & ++ & ++ & ++ & ++ & ++ & ++ \\
\hline
\end{tabular}

$+=$ model data only for the $0.1-$ Sv experiment.

$++=$ model data for both $0.1-$ and $1.0-$ Sv experiments.

water-hosing experiment indicate that the THC weakens in all the models in response to the freshwater input at the ocean surface in high latitudes of the North Atlantic. A 10-yr running mean was performed on the curves to reduce the high-frequency fluctuations of the THC intensity caused by the wind stress variations. Starting from initial conditions, the curves diverge with time as the freshwater is added, indicating differing freshwater sensitivity of the THC among models. The reduction of the THC intensity at the 100th year ranges from 1.3 to $9.7 \mathrm{~Sv}$ (Fig. 2a) or from $9 \%$ to $62 \%$ relative to the control (Fig. 2b). The black curve gives the multimodel ensemble mean of $5.6 \mathrm{~Sv}$, equivalent to a $30 \%$ weakening of the THC after $100 \mathrm{yr}$ of freshwater input. The difference in the THC sensitivity to freshwater input among models is an important issue as it affects all aspects of the climate response (shown later). The numerical schemes, grid resolution, the control climate THC simulation, the location of deep convection, the ocean currents, and the salinity distribution might all be factors in determining this difference. We find no significant correlation between the absolute weakening of the THC and the THC strength in the control runs. For example, the THC intensity simulated by GFDL_R30 and CCC_CGCM2 in the control runs is 24 and $14 \mathrm{~Sv}$, respectively, representing a strong and a weak THC flow. However, both models simulate a similar 9 10-Sv absolute reduction of the THC intensity by the end of the freshwater input period.
Because of the slow adjustment of the deep ocean, the THC doesn't reach equilibrium with the external freshwater forcing during the period of freshwater input. Generally, the THC decreases more rapidly within the first several decades of the 0.1-Sv water-hosing experiment, and the rate of decrease lessens thereafter. In addition, not all models simulate the weakest THC at the end of the freshwater perturbation. The THC intensities in the HadCM3, MIT_UWash, and UToronto models all reach their minimum before the 100th year of the simulation and show signs of reintensification even under the continuing freshwater forcing. This reintensification seems related to a switch of the major deep convection sites to locations north of the hosing area in these models. This shift is likely a result of the experimental design. If the hosing area extended farther north, it is likely that this shift would not occur. Finally, it needs to be noted that the freshwater perturbation of $0.1 \mathrm{~Sv}$ for $100 \mathrm{yr}$ is insufficient to shut down the THC in any of the models presented here.

After the termination of the freshwater perturbation, the THC starts recovering toward its control strength. Thus, no critical point like Stommel's saddle-node bifurcation (Stommel 1961; Rahmstorf 1995) beyond which the THC collapses completely has been passed in these model simulations. The time scale of the THC recovery varies greatly among the models. Two models with the largest fractional decrease, CCC_CGCM2 and ECHAM5/MPI-OM (Fig. 2b), have the longest rein- 


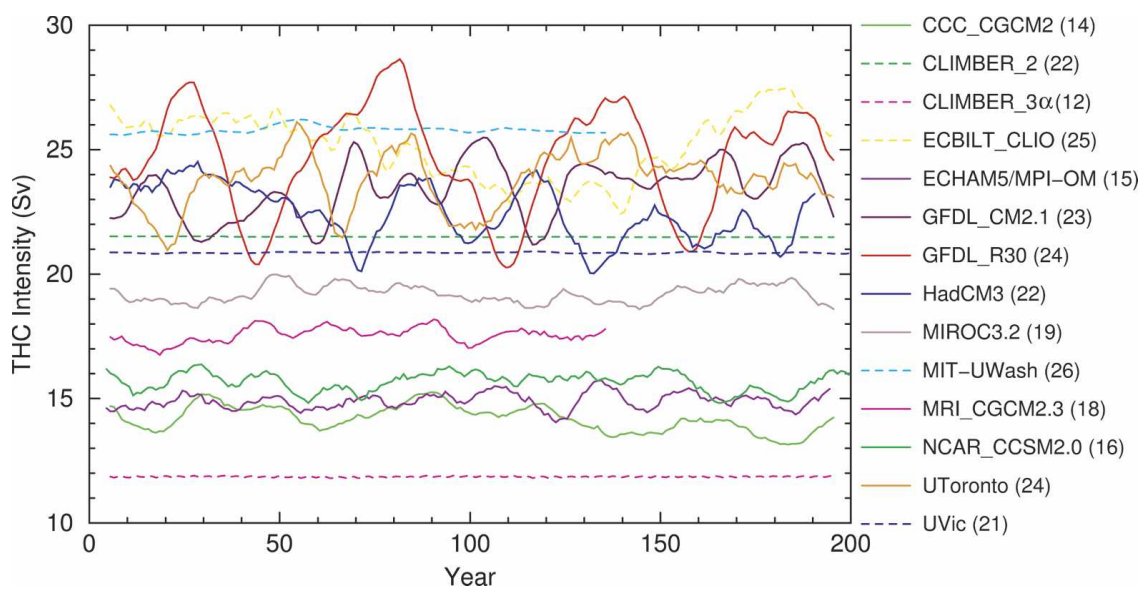

FIG. 1. Time series of the THC intensity (Sv) in the control runs. A 10-yr running mean was performed on the curves to reduce the high-frequency fluctuations of the THC. Solid curves for AOGCMs and dashed curves for EMICs. The numbers after the model names indicate the long-term mean of the THC intensity.
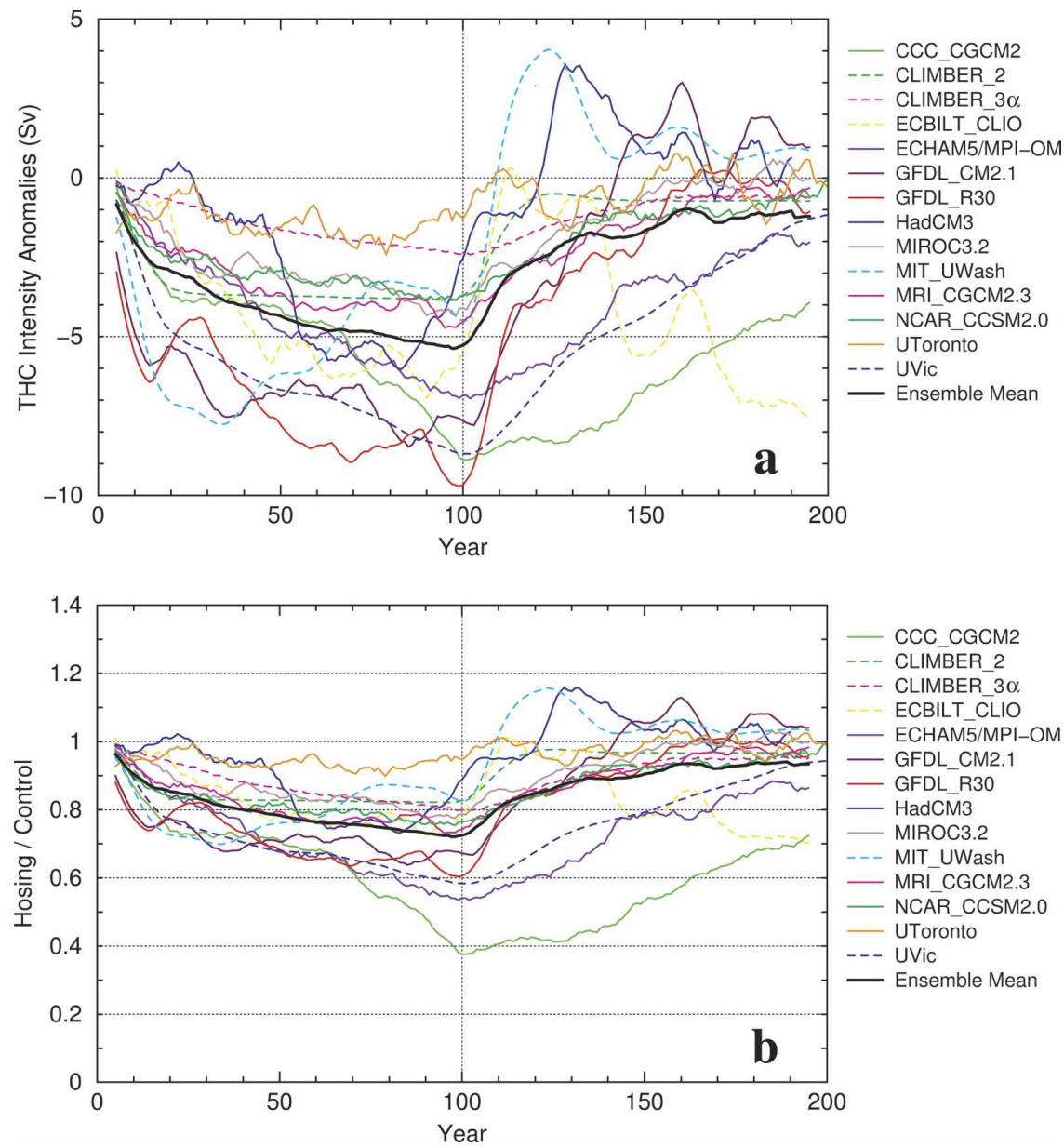

FIG. 2. Time series of the THC intensity anomalies in the 0.1-Sv water-hosing experiments. (a) The absolute value of the anomalies. (b) The relative anomalies compared with the long-term mean of the THC intensity in the control experiments. Solid curves denote AOGCMs and dashed curves denote EMICs. 

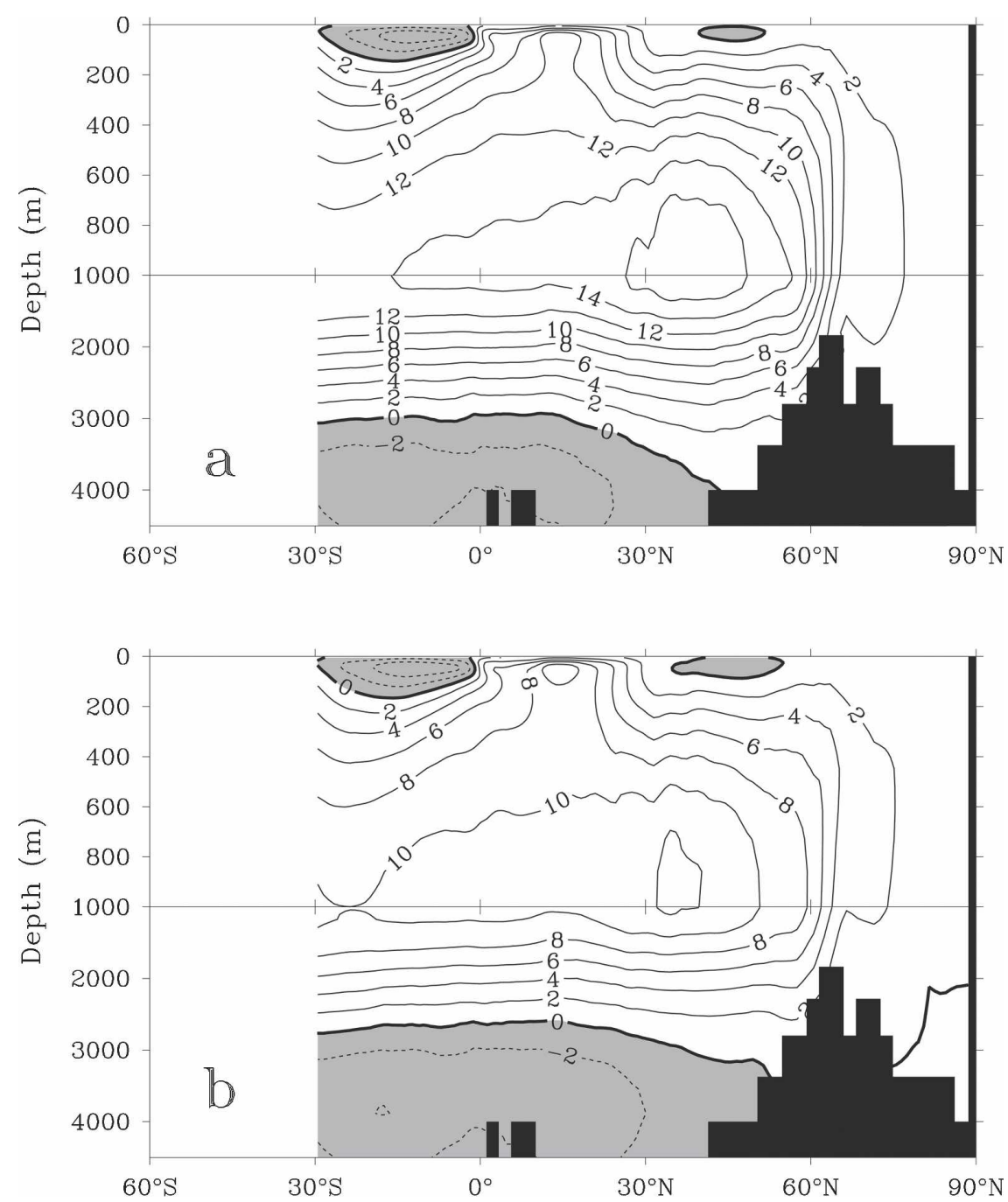

FIG. 3. The meridional overturning streamfunction in the Atlantic (Sv). (a) The ensemble mean of the control runs. (b) The ensemble mean of the 0.1-Sv water-hosing experiment (years 81 100). Negative values are shaded.

tensification time, whereas the THC in other models recovers to a value similar to the control within several decades after the freshwater perturbation ends. The THC in CCC_CGCM2 and ECHAM5/MPI-OM is still well below their respective control intensities at the 200th year. In the GFDL_CM2.1, HadCM3, and MIT_UWash models, it appears that the THC overshoots the control run during the recovery phase but eventually comes back to its control value. It seems that the deep convection activities at the original sites in these models resume quickly after the termination of the freshwater perturbation, while those north of the hosing region do not switch off immediately.

The ensemble mean pattern of the meridional overturning streamfunction in the Atlantic shows that the THC intensity is about $17 \mathrm{~Sv}$ in the control run (Fig. 3a). The sinking motion takes place in $50-70^{\circ} \mathrm{N}$. The northward flow in the upper $1000 \mathrm{~m}$ transports warm and salty seawater to the high latitudes where the seawater is cooled and sinks to the deep ocean. The cold, salty water then flows to the south at 1000 3000-m depth. We note that the overflow across the Greenland-Iceland-Scotland ridge is about 2 4 Sv (Fig. 3a), which is less than many observational estimates (e.g., 6 Sv of Schmitz and McCartney 1993; Hansen and Osterhus 2000). There is a 13-Sv flow across the equator at $30^{\circ} \mathrm{S}$ indicating intense interhemispheric water mass exchange. The anticlockwise cell beneath the THC cell is associated with Antarctic Bottom Water (AABW) formation, while the cells in the upper tropical Atlantic are wind-driven Ekman circulations.

In response to $0.1-\mathrm{Sv}$ freshwater perturbation, the 

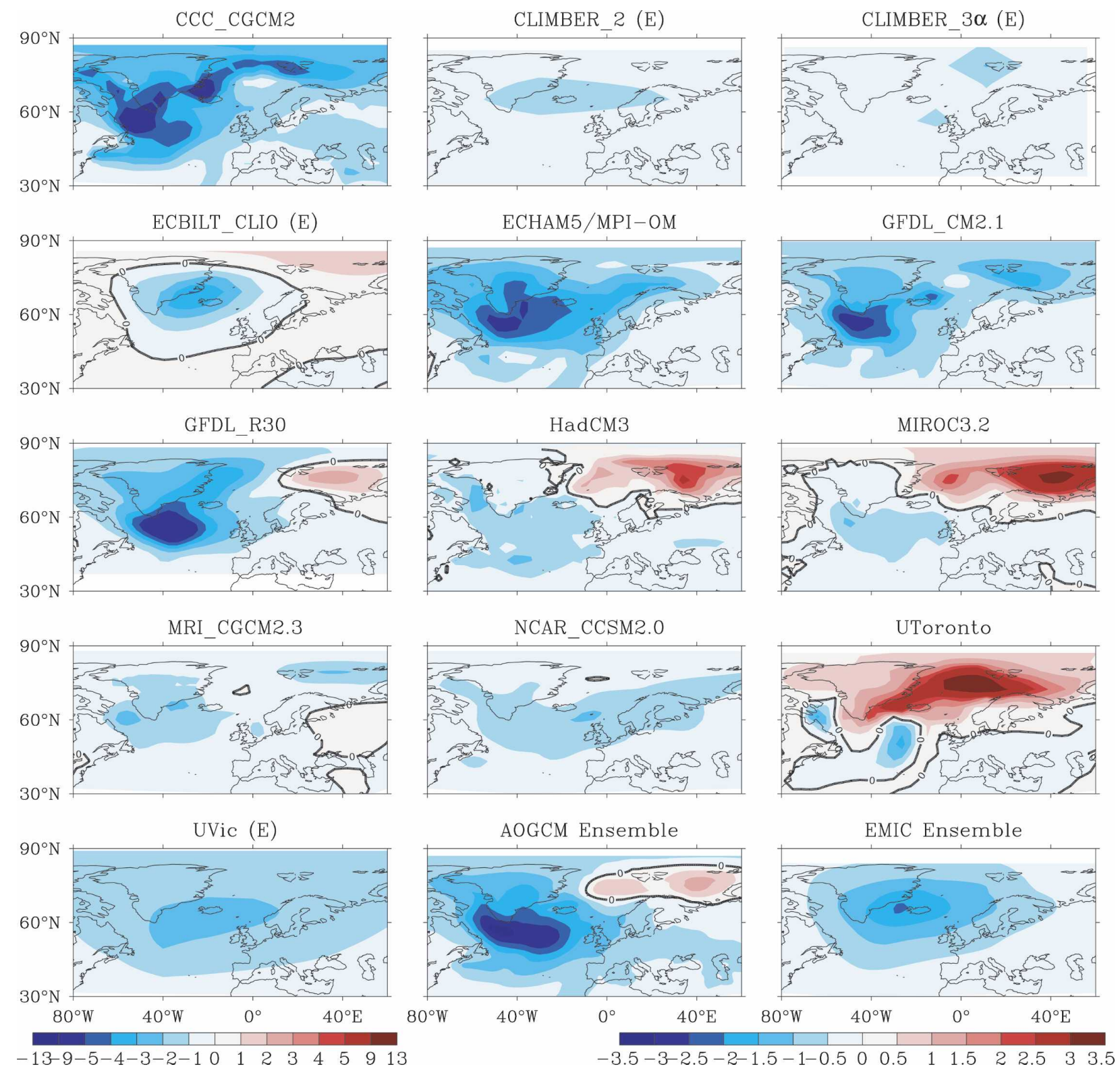

FIG. 4. The SAT anomalies (years $81 \sim 100$ ) simulated by different models in the 0.1-Sv water-hosing experiment. The difference is constructed by subtracting years 81 100 of the hosing integration from years 1 100 of the control. "E" indicates that the model is an EMIC. The last two ensemble panels use a different scale (at lower right).

entire THC cell weakens (Fig. 3b) and the bottom circulation cell intensifies slightly. The maximum streamfunction is about 12 13 Sv, a decrease of about $3 \sim 4 \mathrm{~Sv}$. The flow at $30^{\circ} \mathrm{S}$ drops to about $10 \mathrm{~Sv}$ from $13 \mathrm{~Sv}$. The bottom cell is more than $4 \mathrm{~Sv}$.

\section{2) Surface Air temperature}

Both the magnitude and geographical distribution of the THC-induced surface air temperature (SAT) change; particularly the cooling over the northern
North Atlantic varies greatly among the model simulations. As shown in Fig. 4, four AOGCMs (CCC_CGCM2, ECHAM5/MPI-OM, GFDL_CM2.1, and GFDL_R30) and two EMICs (ECBILT_CLIO and UVic) simulate significant cooling with a pronounced center south of Greenland in response to 0.1-Sv freshwater perturbation. In contrast, the other five AOGCMs (HadCM3, MIROC3.2, MRI_CGCM2.3, NCAR_CCSM2.0, and UToronto) and one EMIC (CLIMBER_3 $\alpha$ ) obtain a very weak temperature decrease over the northern North Atlantic without any notable cooling center. 


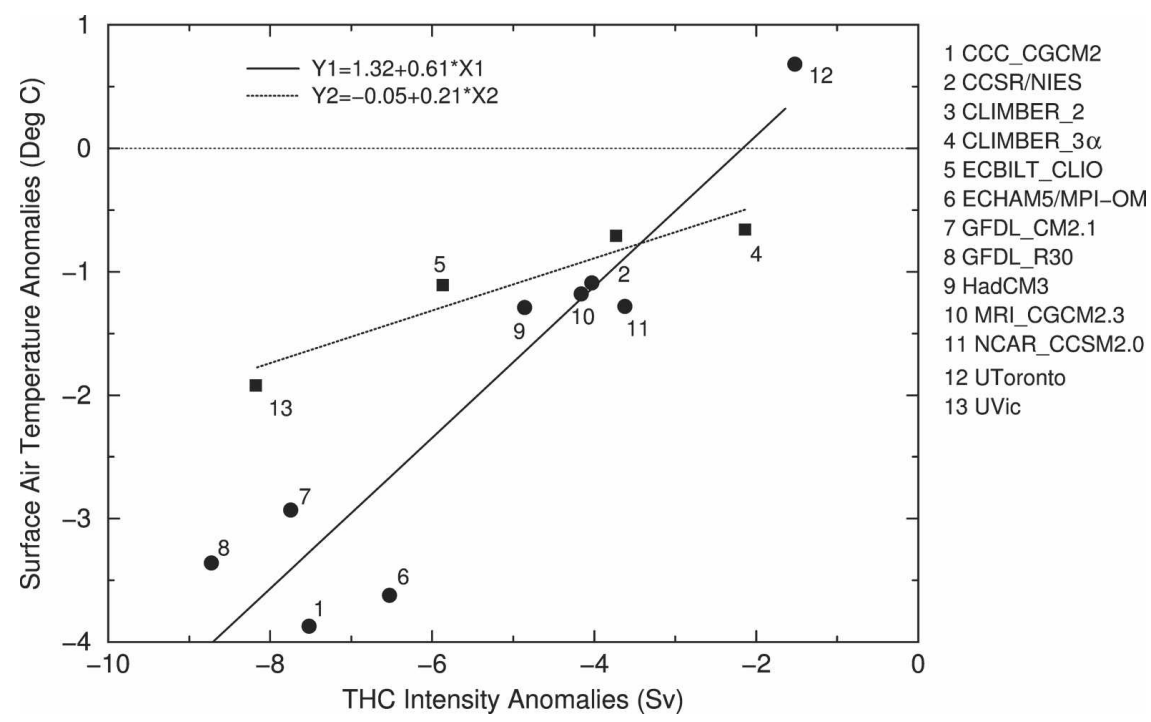

FIG. 5. The SAT anomalies south of Greenland (years $81 \sim 100 ; 45^{\circ} \sim 70^{\circ} \mathrm{N}, 60^{\circ} 10^{\circ} \mathrm{W}$ ) vs the THC intensity anomalies (years $81 \sim 100$ ) in the $0.1-\mathrm{Sv}$ experiment. Dot points: AOGCM; square points: EMICs; solid line: the linear fit based on the AOGCM results; dashed line: the linear fit based on the EMIC results.

The SAT anomaly south of Greenland is plotted as a function of the THC intensity anomaly (Fig. 5). It seems that one can fit two straight lines to the data: one for the AOGCMs and one for the EMICs. However, fitting just one line would produce a result close to the plotted AOGCM line. This indicates that the EMICs results are very close to the AOGCM results. The good correlation [fit to the straight line(s)] indicates that the dynamical behavior of the THC in response to freshwater forcing is crucial to determine the THC-induced cooling.

An interesting feature in Fig. 4 is the warming over the Barents and Nordic Seas. It appears in four AOGCMs (GFDL_R30, HadCM3, MIROC3.2, and UToronto) and one EMIC (ECBILT_CLIO). The warming in this region is as large as $10^{\circ} \mathrm{C}$ in the MIROC3.2 and UToronto results, and $5^{\circ} \mathrm{C}$ in the HadCM3. It can be larger in magnitude than the cooling south of Greenland. The warming is caused by the northward shift of oceanic deep convection (Fig. 10), the resulting increase in the northward heat transport in the high latitudes of the North Atlantic (Fig. 8b) and then amplified by a sea ice feedback (Fig. 9c). The perturbation freshwater flux weakens the deep convection in the $50^{\circ} \sim 70^{\circ} \mathrm{N}$ belt. It is possible for the sinking to take place farther north in the Barents Sea, where no perturbation freshwater flux is directly imposed and conditions can be favorable for water mass formation to occur. As a result, in some models the sinking moves north into the Barrents Sea. The ECBILT_CLIO, GFDL_R30, HadCM3, and MIROC3.2 models indeed show a positive sea surface salinity (SSS) anomaly in the Barents Sea associated with the enhanced deep water formation there, while the UToronto model shows positive anomalies in the Greenland-IcelandNorwegian (GIN) Seas and south of Greenland (Fig. 10).

The increased convection brings relatively warmer seawater from the ocean interior to the surface. This heating from below reduces the sea ice thickness (Fig. 9c) and pushes back the sea ice boundary. The lower atmosphere no longer overlies sea ice that insulates the atmosphere from the ocean. The heat from the ocean then warms the overlying atmosphere, leading to the large SAT changes seen in Fig. 5 in some models. For the models in which the simulated sea ice in the Barents and Nordic Seas is thick, this warming can be quite large. After combining the cooling and warming, the SAT anomalies averaged over $50^{\circ} \sim 70^{\circ} \mathrm{N}$ of the North Atlantic (Fig. 6) range from $-4.4^{\circ} \mathrm{C}$ in the GFDL_R30 model to $+1.0^{\circ} \mathrm{C}$ in the UToronto model at the 100 th year.

The ensemble mean of the SAT change simulated by the participating models helps summarize the signal and outline the robust features. In the 0.1-Sv waterhosing experiments, the slowdown of the THC results in a reduction of northward heat transport and vertical heat transport (due to reduced vertical mixing), leading to a robust cooling over the northern North Atlantic (Fig. 7b). The maximum cooling of up to $3^{\circ} \mathrm{C}$ occurs south of Greenland, corresponding to the typical deep convection site in the Labrador Sea. The sea ice exten- 


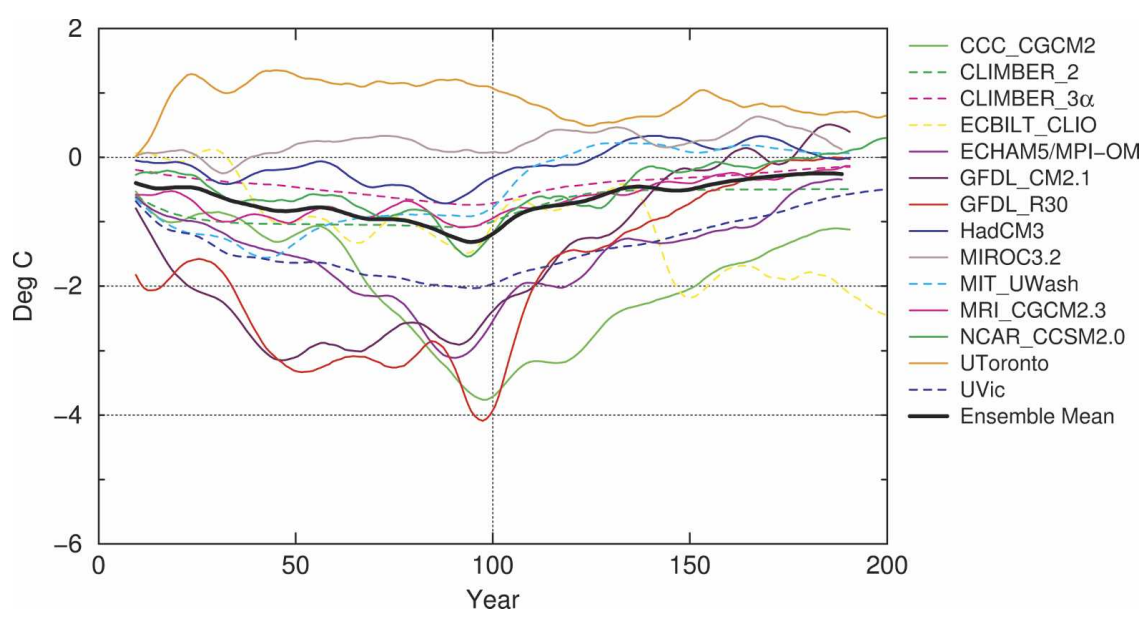

FIG. 6. Time series of the SAT anomalies in the 0.1-Sv water-hosing experiment (the mean over $50^{\circ} \sim 70^{\circ} \mathrm{N}$ of the northern North Atlantic).

sion and the increase of sea ice thickness (Fig. 9c) further enhance the cooling by reflecting more solar radiation and inhibiting the heat exchange between the atmosphere and the ocean.

The cooling area extends eastward with a $0.5^{\circ} \sim 1^{\circ} \mathrm{C}$ temperature decrease over most of western Europe. The SAT changes in the Barents and Norwegian Seas are the most uncertain regions as indicated by the large local intermodel standard deviation (Fig. 7b and Fig. 4). It is unclear what causes this wide variation in model responses in these regions. It is possible that some of the variation is related to the models ability (or lack) to simulate the deep water formation in the Nordic Seas.

The cooling over the northwest North Atlantic and warming over the northeast North Atlantic reflects a wave-like atmospheric circulation pattern in the middle-high latitudes of the Northern Hemisphere, which is stimulated by the freshwater perturbation. In the wintertime, there is a longwave ridge in the flow over eastern Pacific and Atlantic Oceans and troughs over the east coasts of North Atlantic and Asia. It appears that the wintertime ridges flatten in the freshwater perturbation integrations, leading to cooling over the two oceans (Fig. 7b) with smaller changes over the middle-latitude continents. The seasonality and atmospheric circulation response to the freshwater perturbation could be the subject of further investigations.

The response in the Southern Hemisphere to the slowdown of the THC is much smaller than seen in the Northern Hemisphere. Generally there is a small warming in the Southern Hemisphere. As the THC weakens, the northward heat transport is reduced, keeping more heat in the Southern Hemisphere. This additional heat leads to the small SAT warming found there. Apparently, the maximum warming is induced by the enhancement of the deep convection and sea ice

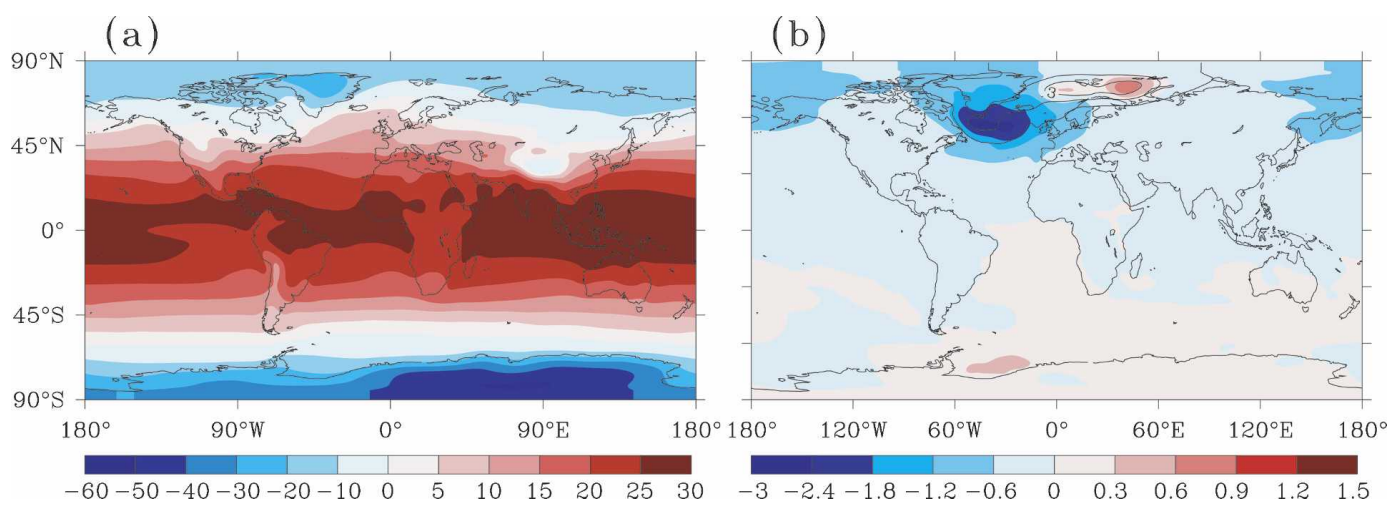

FIG. 7. The SAT $\left({ }^{\circ} \mathrm{C}\right)$. (a) The ensemble mean of the control among the participating climate models. (b) The ensemble mean of the anomalies (color shades) between the 0.1-Sv water-hosing experiment and the control experiment (years 81 100) and std dev among model simulations (solid lines). 

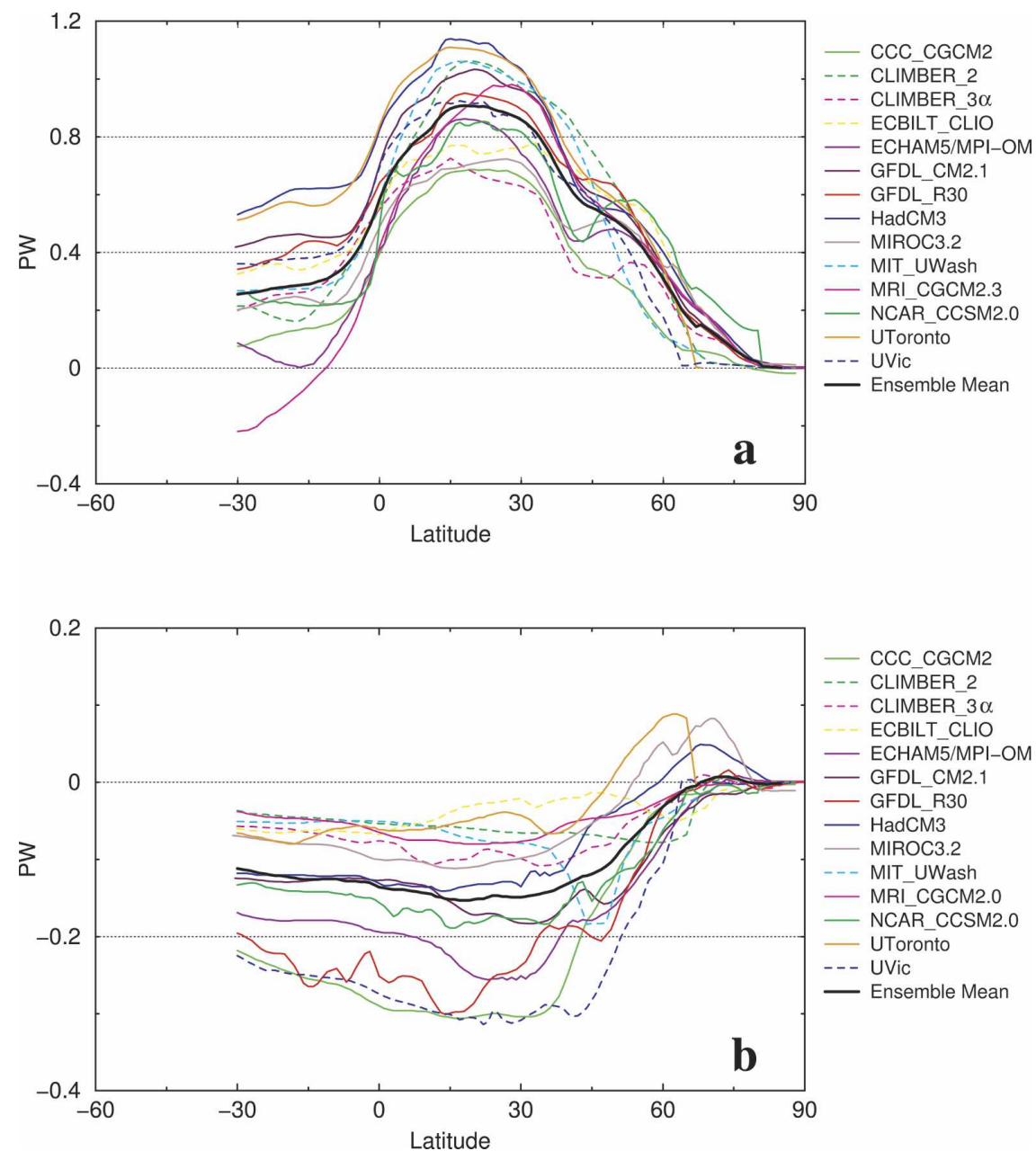

FIG. 8. Northward heat transport in the Atlantic Ocean. (a) The control run.

(b) Anomalies in the 0.1-Sv water-hosing experiment.

change in the Weddell Sea related to the increase in AABW formation shown by Fig. 3. The north-south deep convection coupling may therefore play a very important role in the global-scale north-south climate connection (Crowley 1992; Stocker 2002).

Much of the SAT change essentially stems from the change of northward heat transport in the Atlantic (Fig. 8 ) as noted above. The heat transport in the Atlantic is uniformly northward (Fig. 8a), differing from the simulation in the Pacific Ocean, where the heat transport is poleward. Among the models analyzed here, the maximum northward heat transport at about $20^{\circ} \mathrm{N}$ in the North Atlantic Ocean ranges from 0.7 to $1.1 \mathrm{PW}(1 \mathrm{PW}=$ $\left.10^{15} \mathrm{~W}\right)$. This is weaker than the observed estimate of about 1.3 PW, but within the uncertainty range of the observationally based estimates using the high-quality hydrographic data gathered in the World Ocean Circulation Experiment (Ganachaud and Wunsch 2000; Stammer et al. 2003). After the slowdown of the THC, the northward heat transport in the Atlantic decreases (Fig. 8b). The multimodel ensemble mean gives a maximum decrease about $0.13 \mathrm{PW}$ around $20^{\circ} \mathrm{N}$.

\section{3) OCEAN TEMPERATURE AND SALINITY}

The multimodel ensemble change of SST after the slowdown of the THC (Fig. 9a) bears a similar pattern to that of the surface air temperature (Fig. 7b). The SST decrease up to $3^{\circ} \mathrm{C}$ south of Greenland extends the sea ice coverage in this region. The slight SST increase in the Barents Sea corresponds to the SAT warming seen in this area in Fig. 7b. The slight warming of the SST in the South Atlantic, induced by the slowdown of the THC, spreads throughout the Southern Ocean via the Antarctic Circumpolar Current (ACC). The fulcrum of the SST changes is the equatorial Atlantic. Besides the thermal effect on the atmosphere, the decrease of the SST over the northern North Atlantic also provides the so-called temperature advection feedback to stabilize 
(a)

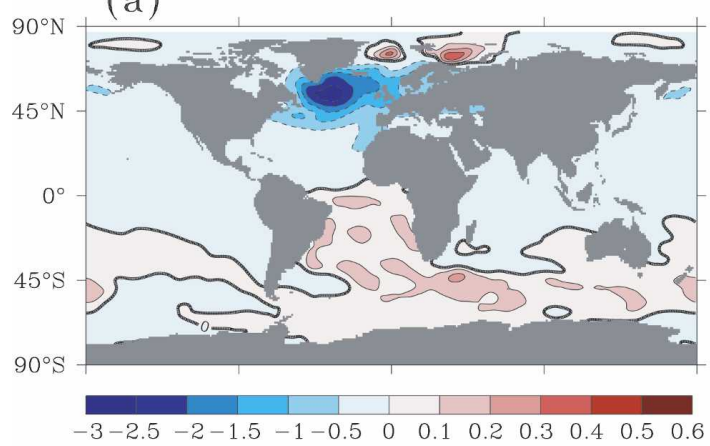

(c) (b)

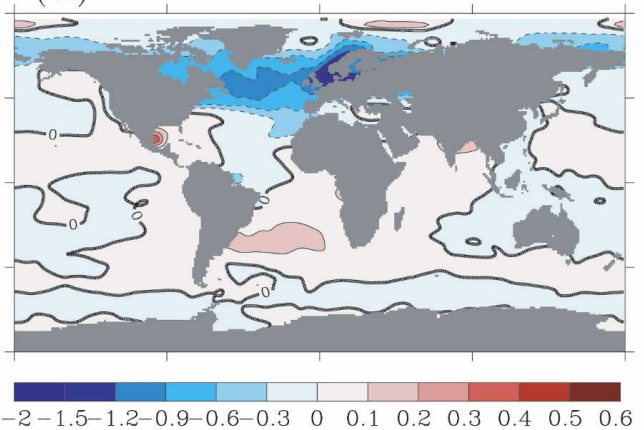

(d)

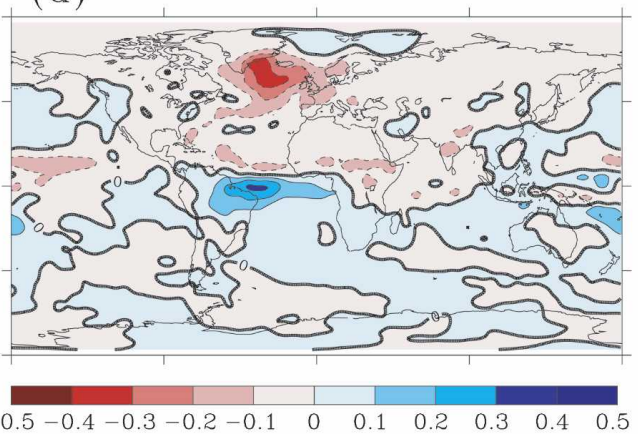

(f)

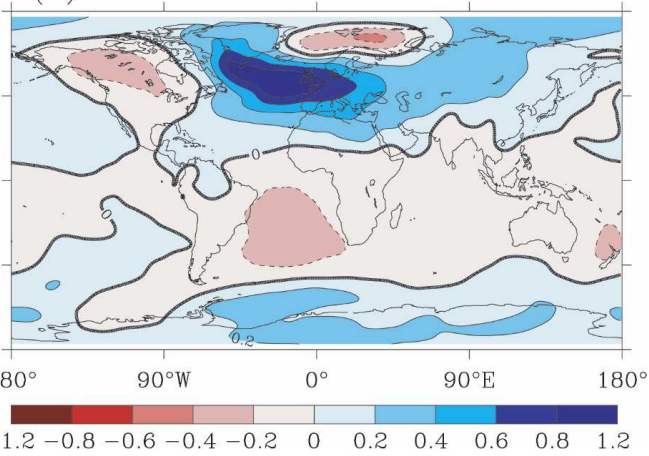

FIG. 9. Geographical distribution of the ensemble mean anomalies in the 0.1-Sv experiment. Years 81 100. (a) SST $\left({ }^{\circ} \mathrm{C}\right),\left(\right.$ b) SSS (psu), (c) sea ice thickness (m), (d) $\left(\mathrm{mm} \mathrm{day}^{-1}\right),(\mathrm{e})$ net freshwater flux into the ocean $(\mathrm{mm}$ day $^{-1}$ ), and (f) sea level pressure (mb).

the THC by increasing the surface seawater density. But this effect is secondary in comparison with the density decrease induced by the high-latitude freshening due to the hosing.

The decrease in SSS over the northern North Atlantic is a direct result of the additional freshwater input and the response to the weakening of the THC. The multimodel ensemble mean shows that the maximum freshening occurs in the $50^{\circ} \sim 70^{\circ} \mathrm{N}$ latitudes with SSS decrease of about 1.2 psu. However, different models simulate distinctly different geographical distribution of the SSS anomalies (Fig. 10). For example, the maximum freshening can occur at the eastern, middle, or western part of $50^{\circ} \sim 70^{\circ} \mathrm{N}$ latitudes of the North Atlantic. Some models obtain a positive SSS anomaly around the Barents Sea while some others simulate a negative anomaly there. The differences in the SSS response could result from many factors such as the location of the deep convection sites or the exact details of the time mean oceanic currents. Generally, the North Atlantic surface water becomes fresher and the South Atlantic becomes saltier during the slowdown of the THC. The salinity increase in the Gulf of Mexico and the Caribbean Sea is a consequence of the change of evaporation and precipitation there (Fig. 9e). Sedimentological data have confirmed that the SSS in the Caribbean Sea in- 

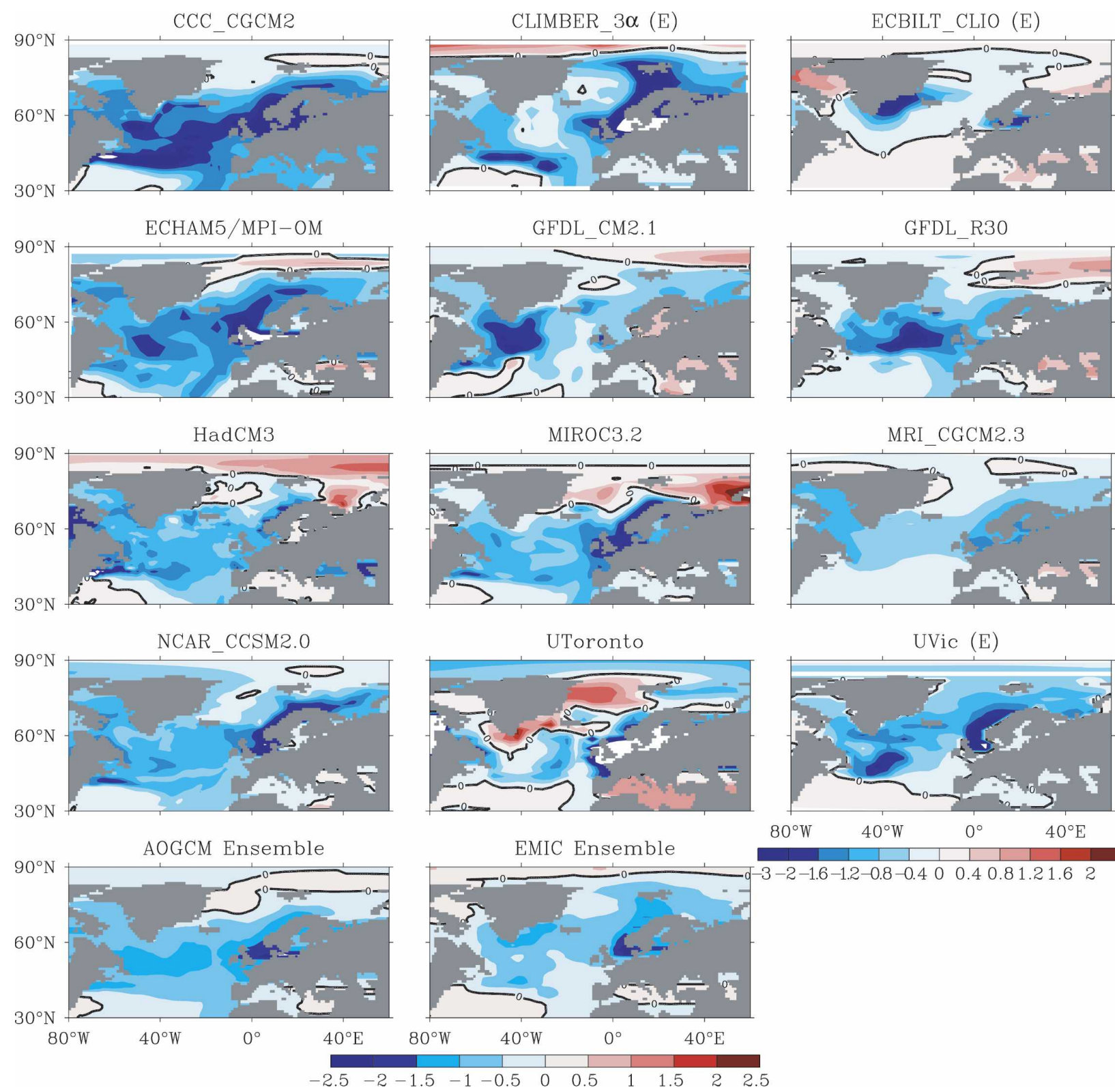

FIG. 10. The SSS anomalies (years 81 100) simulated by different models in the 0.1-Sv water-hosing experiment (psu).

deed has an antiphase relationship with North Atlantic Deep Water formation during the last glacial cycle (Schmidt et al. 2004). Hence, the salinity over the western tropical-subtropical North Atlantic could play a crucial role in the study of past evolution of the THC.

Unlike SST that can thermally feedback on the overlying atmosphere, SSS plays its major role in the dynamics of the THC and other oceanic circulations. The decrease in salinity in northern North Atlantic and the increase in the tropical-subtropical western North Atlantic create a sharp north-south salinity gradient around $40^{\circ} \mathrm{N}$. The northward salinity flux across $40^{\circ} \mathrm{N}$ increases subsequently accompanying the ocean horizontal mixing process and gyre circulation. This increase in northward salinity flux in the upper ocean prevents the runaway salinity decrease in the northern North Atlantic induced by the positive salinity-advection feedback associated with the THC (Stommel 1961).

The large value of salinity decrease (Fig. 9b) and small value of model deviation (not shown) imply that the Labrador Sea and surrounding oceans are the most susceptible regions to the freshwater perturbation induced either by the increase of $P-E$ or by the melting 

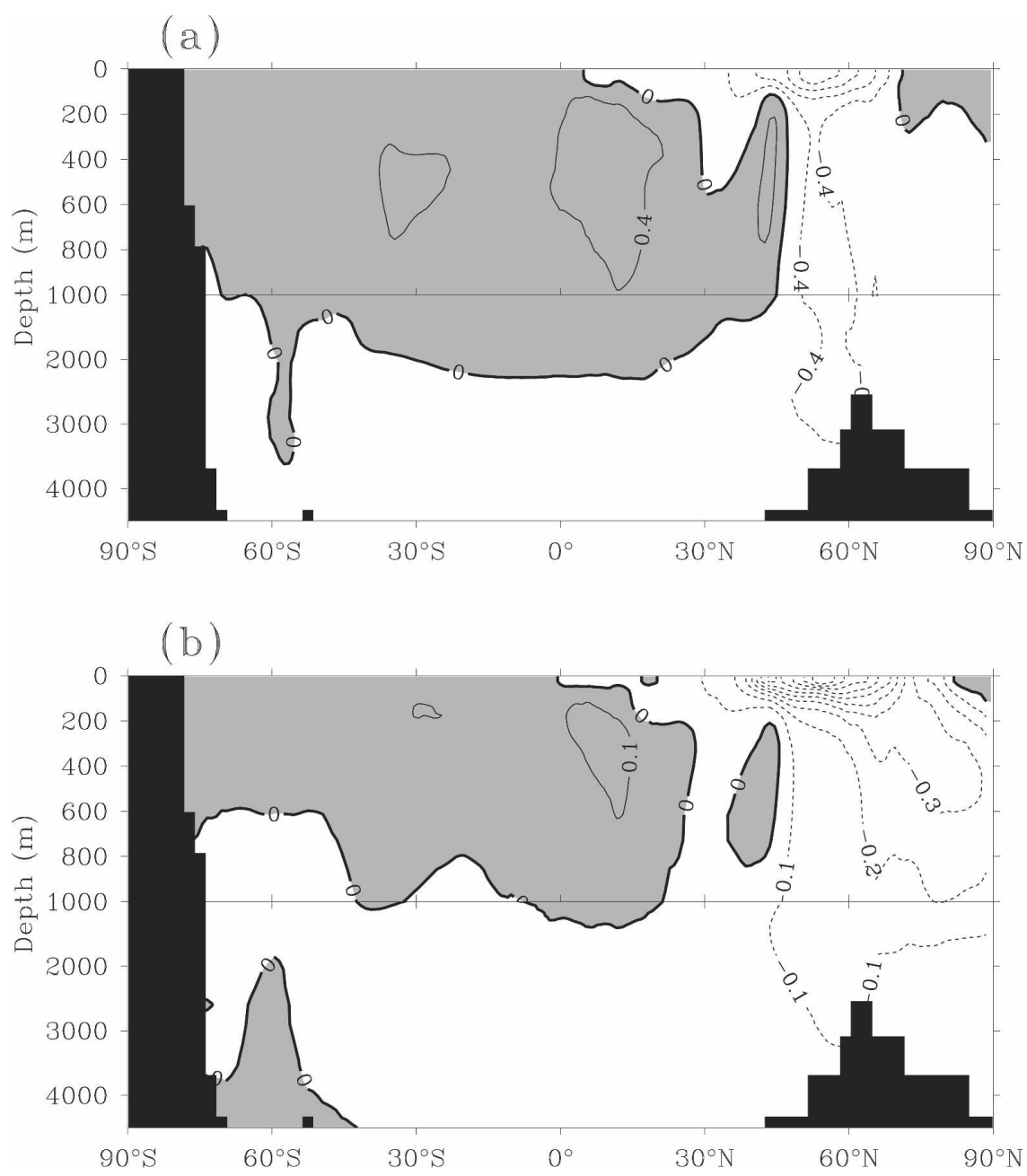

FIG. 11. The ensemble mean of ocean temperature and salinity anomalies zonally averaged in the Atlantic in the 0.1-Sv experiment: (a) temperature $\left({ }^{\circ} \mathrm{C}\right.$ ) and (b) salinity (psu). Positive values are shaded.

of the nearby ice sheet (Wood et al. 1999; Weaver and Hillaire-Marcel 2004; Cheng and Rhines 2004). The lack of the direct supply of high-salinity seawater makes the deep convection and deep water formation in these regions easier to shut down.

The zonally averaged ocean temperature (Fig. 11a) and salinity (Fig. 11b) in the Atlantic display the distribution of the anomalies in the ocean interior. The warming through the water column at about $45^{\circ} \mathrm{N}$ (Fig. 11a) is evidence of the weakening of high-latitude ventilation. The ocean warming also takes place in the intermediate layer south of $45^{\circ} \mathrm{N}$ because of the reduction of the northward heat transport. These changes in ocean temperature have a large impact on local sea level (not shown). The sea level in the North Atlantic is also greatly affected by the change of the strength of the THC (Levermann et al. 2005).
In terms of ocean salinity, the freshwater accumulates at the northern North Atlantic to form a low salinity, low density cap inhibiting oceanic convection and vertical mixing (Fig. 11b). Part of the perturbation freshwater is carried downward to the deep ocean by the sinking branch of the THC. It is also apparent that the Arctic gets fresher because of the northward transport of the perturbation freshwater beneath the surface layer. Most of the intermediate ocean south of $45^{\circ} \mathrm{N}$ becomes saltier because of the reduction in the northward transport of salty water.

\section{4) SEA ICE}

Sea ice is more extensive and its thickness increases in the Labrador Sea after the slowdown of the THC (Fig. 9c). These changes provide positive feedbacks to enhance the surface air temperature anomalies induced 
by the reduction of the northward heat transport in the Atlantic (Fig. 7b). However, because of the northward shift of the deep convection sites and the enhancement of the deep convection, the sea ice retreats and its thickness reduces in the Barents and GIN Seas in the multimodel ensemble. At the southern end of the Atlantic, the sea ice mass also reduces as a result of the enhancement of the deep convection in the Weddell Sea (Fig. $3 b)$. As discussed earlier, more heat is transported from the interior ocean to the surface to melt the sea ice.

\section{5) Precipitation}

Previous research on the climate impacts of a slowdown/shutdown of the THC has focused on the surface air temperature change over the high-latitude region. Recently, attention has been given to the tropical-subtropical Atlantic emphasizing the impact of the THC on the hydrological cycle there (Chiang and Koutavas 2004). The importance of the hydrological cycle over the tropical Atlantic lies in its direct influence on the Amazon's biotic system, the Sahel drought, and the low-latitude SSS. The latter helps regulate the intensity of the THC through northward salinity advection, providing complex feedbacks on the dynamical behavior of the THC (Vellinga and Wood 2002).

After the slowdown of the THC, a dipole pattern in precipitation appears with positive anomalies over the equatorial Atlantic and the Amazon and negative anomalies over the tropical North Atlantic (Fig. 9d). The positive anomaly band spans the entire Atlantic just south of the equator, from the Amazon to central Africa with the center close to northeastern Brazil. Given the annual mean position of the Atlantic ITCZ is in the Northern Hemisphere, this dipole pattern is a signal of the southward shift of the ITCZ and Hadley circulation. The signal is much more significant in the 1.0-Sv water-hosing experiment after the shutdown of the THC (Fig. 16; see below).

The southward shift of the maximum rainfall belt over the Atlantic is a robust feature in the AOGCM simulations (Fig. 12). Most AOGCMs simulate a drying over the tropical North Atlantic. This drying may enhance the SSS in the low-latitude North Atlantic and act to reintensify the THC after the hosing stops. In contrast, the southward shift of the Atlantic ITCZ does not appear in the simulations of EMICs because of their coarse resolution and reduced complexity, particularly for the atmospheric dynamical processes (Fig. 12, EMIC ensemble).

The shift of the Atlantic ITCZ is mainly attributable to the interhemisphere seesaw pattern of the temperature change over the Atlantic. Notice that there is also a precipitation change dipole over the equatorial $\mathrm{Pa}$ - cific. Given the large total precipitation there, the statistical significance of this dipole remains unclear and is the subject for future investigations.

Besides the low-latitude Atlantic, another region in Fig. 9d where the precipitation also undergoes significant change is the North Atlantic along the midlatitude storm track. This decrease is closely related to the temperature decrease over the northern North Atlantic and the resulting weakening of the Icelandic low (shown later).

\section{6) Net Freshwater Flux OVER the oceAN SURFACE}

The regions where deep convection and deep water formation take place are likely to be the regions where the THC is the most sensitive to freshwater perturbations. However, the THC can feel any change of the net freshwater flux along its "catchment" region. Essentially, the catchment region is the upper route of the THC including the tropical-subtropical Atlantic. Manabe and Stouffer (1995) found that freshwater flux anomalies away from the oceanic convection sites are less effective in causing changes in the THC than the same anomalies over the oceanic convection sites. Therefore, the evolution of the THC intensity actually is a result of the complex interplay of the net freshwater flux changes in the catchment region. It has been shown in the preceding section that the freshwater addition over the northern North Atlantic alters the hydrological cycle in the low-latitude Atlantic. The subsequent freshwater flux anomalies over the tropical-subtropical North Atlantic can provide feedbacks on the freshening over the high-latitude North Atlantic and the intensity of the THC. The net freshwater flux (precipitation plus runoff minus evaporation) anomalies in the 0.1-Sv water-hosing experiment (Fig. 9e) show a large positive area over the northern North Atlantic resulting from the perturbation freshwater input. Over the low-latitude Atlantic, there is a dipole pattern similar to Fig. $9 \mathrm{~d}$. We expect that the change of evaporation over the low-latitude Atlantic is relatively small when compared to the local precipitation changes. It seems therefore that the precipitations are the main contributor to the net freshwater flux anomalies. It is also clear in Fig. 9e that both the local freshwater fluxes from the atmosphere and the runoff of Amazon River increase after the southward shift of the Atlantic ITCZ. The negative anomalies over the tropical North Atlantic tend to enhance the SSS over low-latitude Atlantic and are then advected northward, offsetting some of the freshening over the high latitude of the North Atlantic (Lohmann 2003). This enhancement is also clear in the vertical cross-section picture (Fig. 11b). 

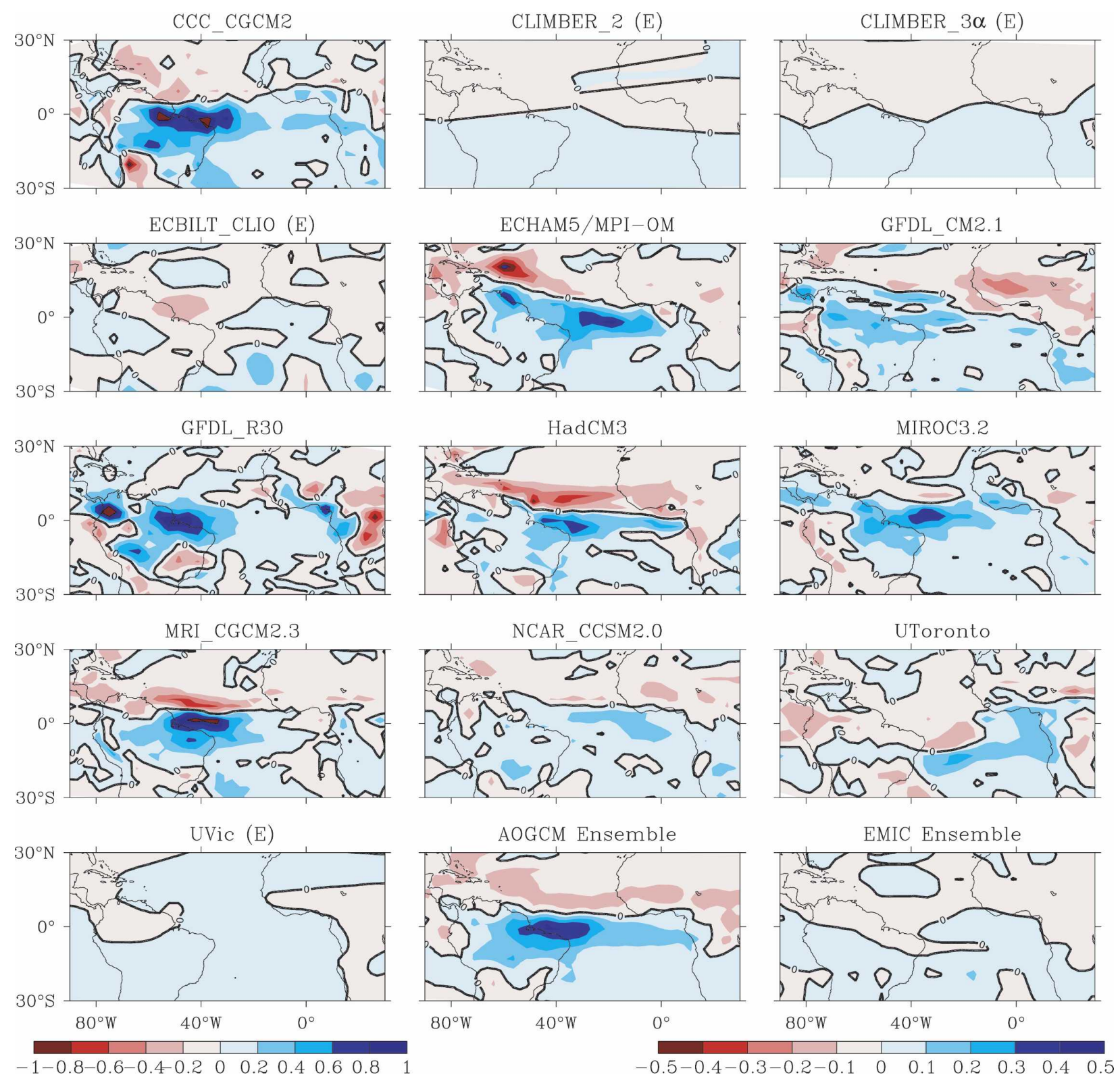

$\begin{array}{lllllll}-1-0.8-0.6-0.4-0.2 & 0 & 0.2 & 0.4 & 0.6 & 0.8\end{array}$

$\begin{array}{lllllll}-0.5-0.4-0.3-0.2-0.1 & 0 & 0.1 & 0.2 & 0.3 & 0.4 & 0.5\end{array}$

FIG. 12. Precipitation anomalies and the southward shift of the ITCZ over the tropical Atlantic in individual model simulations $\left(\mathrm{mm} \mathrm{day}^{-1}\right)$ in the $0.1-\mathrm{Sv}$ experiment.

\section{7) Sea level Pressure}

The North Atlantic Oscillation (NAO) is the dominant pattern of the climate variability in the North Atlantic region. The close interaction between the THC and the NAO is a consequence of their major centers of action being collocated over or near the northern North Atlantic. The NAO causes changes to the THC intensity through anomalous wind stress and buoyancy fluxes associated with positive and negative NAO phases (Delworth and Dixon 2000). On the other hand, a slowdown/shutdown of the THC causes SST decrease in the northern North Atlantic, weakening the Icelandic low, and therefore influencing the phase of the NAO. After the slowdown of the THC, a positive anomaly of sea level pressure of up to $1.5 \mathrm{hPa}$ appears south of Iceland, and the Icelandic Low becomes weaker (Fig. 9f) in the multimodel ensemble.

\section{b. 1.0-Sv water-hosing experiments}

As indicated in Table 2, only a subset of models performed this second perturbation integration. Since the imposed 1.0-Sv freshwater forcing is an order of mag- 


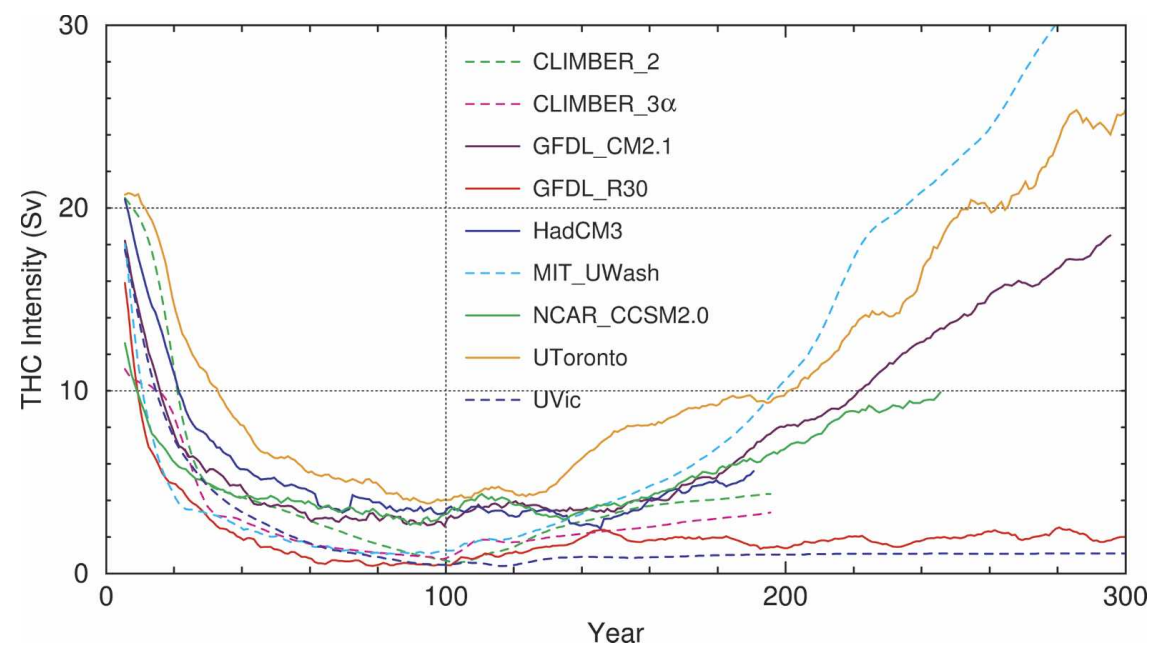

FIG. 13. Time series of the THC intensity evolution in the $1.0-\mathrm{Sv}$ water-hosing experiments.

nitude larger, the climate changes are expected to be much larger than those in the 0.1-Sv hosing case.

In response to the 1.0-Sv freshwater input, the THC collapses to a near shutdown condition within $50 \mathrm{yr}$ of the start of the freshwater perturbation (Fig. 13). Four models (GFDL_CM2.1, MIT_UWash, NCAR_CCSM2.0, and UToronto) show a rapid reintensification of the THC once the freshwater is eliminated at the 100th year. Although the integration time is too short for a full response, the shutdown of the THC in the HadCM3 is also likely a reversible process. In contrast, the THC remains inactive in the GFDL_R30 and UVic models even after the termination of the freshwater perturbation, indicating that the THC may have changed states in these two models.

The AOGCM ensemble mean of the SAT anomalies after the shutdown of the THC shows a large cooling in the North Atlantic (Fig. 14a). The maximum cooling of up to $12^{\circ} \mathrm{C}$ occurs between Scotland and Iceland, while western and northern Europe becomes $4^{\circ} \sim 10^{\circ} \mathrm{C}$ colder. The temperature over the tropical North Atlantic also decreases about $2^{\circ} \sim 3^{\circ} \mathrm{C}$. The maximum warming of up to $2.4^{\circ} \mathrm{C}$ occurs over the South Atlantic along the African coast. This warming is induced by the redistribution of the oceanic heat carried by the THC.

On average, the Northern Hemisphere as a whole cools about $2.3^{\circ} \mathrm{C}$ and the Southern Hemisphere warms about $0.3^{\circ} \mathrm{C}$. Consequently, there is a global cooling of about $1{ }^{\circ} \mathrm{C}$ after the shutdown of the THC. The EMICs simulate similar SAT anomaly patterns as the AOGCMs but with relatively smaller magnitude (Fig. 14b). The ensemble EMIC mean cooling of the Northern Hemisphere is about $1.4^{\circ} \mathrm{C}$ with the maximum up to $7^{\circ} \mathrm{C}$ in the northern North Atlantic. The warming in the
Southern Hemisphere is also smaller in the EMICs than in the AOGCMs.

After the collapse of the THC, the northward heat transport in the Atlantic Ocean is greatly reduced in most models (Fig. 15). This reduction in the northward heat transport leads to the pattern of SAT changes noted above where the Northern Hemisphere cools and the Southern Hemisphere warms. The magnitude of the local SST and SSS decreases in the North Atlantic can be up to $10^{\circ} \mathrm{C}$ and $10 \mathrm{psu}$, respectively (not shown). The maximum decrease in SST and SSS occurs at the eastern North Atlantic. Most of the North Atlantic north of $50^{\circ} \mathrm{N}$ is covered by sea ice in winter.

The southward shift of the Atlantic ITCZ is very significant in AOGCM simulations of the 1.0-Sv waterhosing experiment (Fig. 16). There is a strong negative anomaly over the entire North Atlantic and positive anomalies over the South Atlantic after the shutdown of the THC. In the multimodel AOGCM ensemble, the maximum change in precipitation is about $2.5 \mathrm{~mm}$ day ${ }^{-1}$ occurs at $8^{\circ}$ latitude north and south of the equator. On the other hand, the precipitation response in the EMICs' ensemble is much weaker than that seen in the AOGCM results. These precipitation changes lead to negative freshwater flux anomalies over the North Atlantic (not shown). These atmospheric flux anomalies tend to compensate for the horizontal advection of the fresh salinity anomalies from the North Atlantic in the tropical-subtropical North Atlantic. In the western tropical and subtropical North Atlantic, the atmospheric flux anomalies tend be larger than the advective flux anomalies, so that the SSS increases. In the rest of the tropical and subtropical North Atlantic, the SSS decreases indicating that the advective flux 


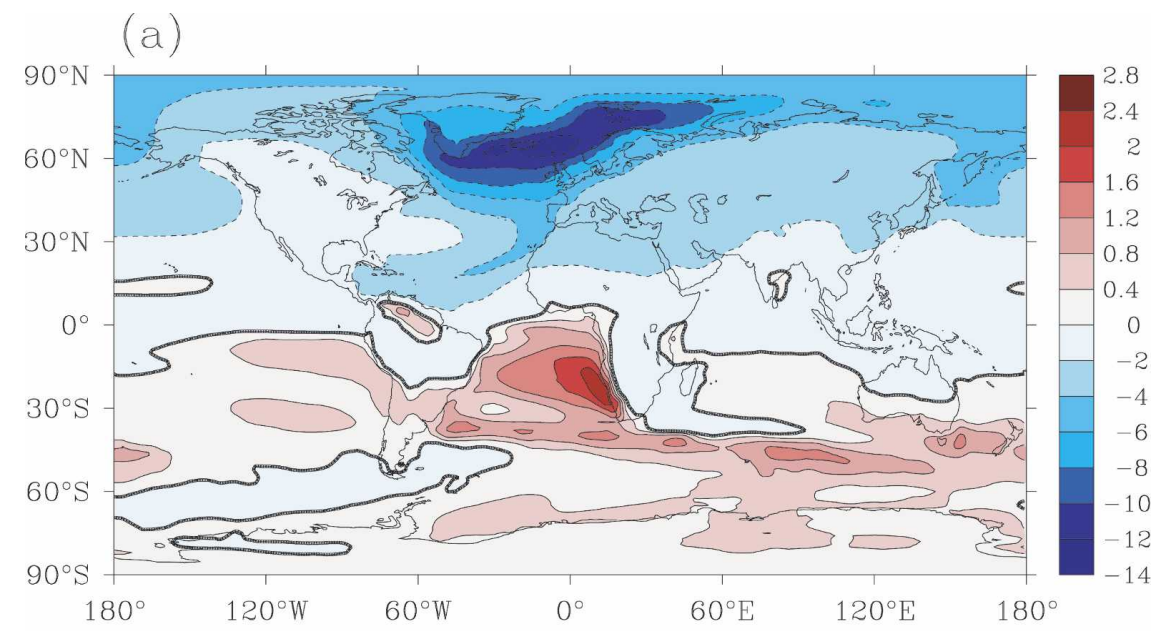

(b)

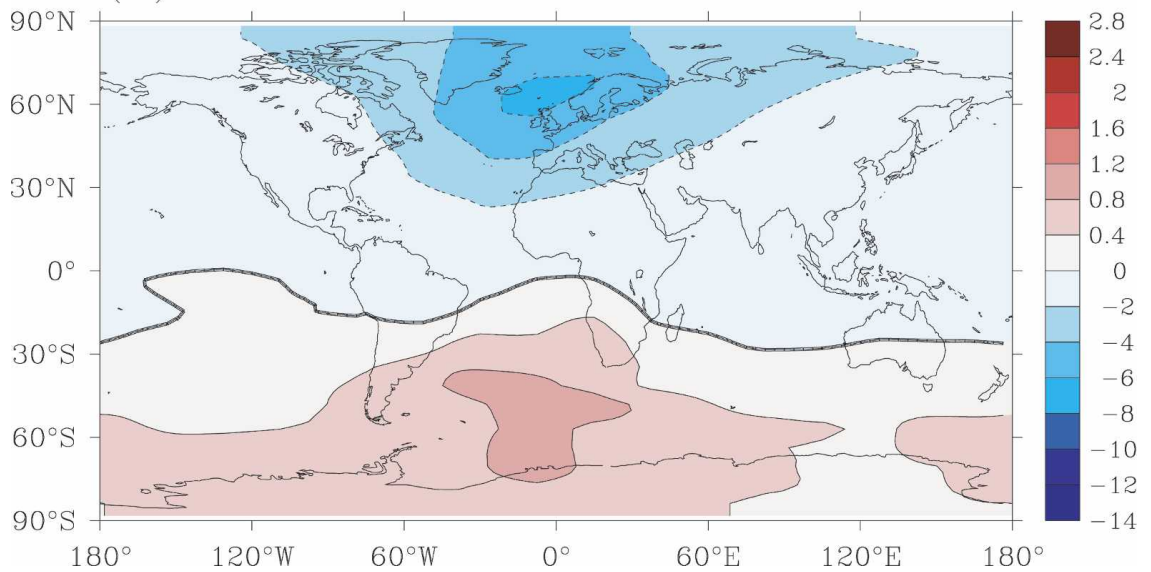

FIG. 14. The SAT anomalies (years $81 \sim 100$ ) in the 1.0-Sv experiment: (a) AOGCM ensemble and (b) EMIC ensemble.

anomalies have a large impact on the SSS changes there.

\section{Discussion and conclusions}

The coordinated experiments conducted by CMIP/ PMIP are designed to improve our understanding of the THC response. Through the increased understanding, the uncertainty associated with the THC response should decrease. This paper represents a first attempt to document the model's THC response in these coordinated experiments.

A $0.1-\mathrm{Sv}$ freshwater perturbation over the $50^{\circ} \sim 70^{\circ} \mathrm{N}$ of the North Atlantic approximately resembles the projected freshwater flux anomalies over the high latitudes of the North Atlantic induced by global warming a century or more in the future. In response to this freshwater input, the THC gradually weakens by $30 \%$ at the 100th year in the multimodel ensemble mean, with a range of results from the individual models. No model presented here simulates a complete THC shutdown during the 100-yr 0.1-Sv perturbation.

It is important to remember the experimental design when applying these results to either past or future climates. A caveat that applies to future climates is that the role of the freshwater flux anomalies in the low latitudes of the Atlantic is not taken into account. It has been demonstrated that the freshwater flux anomalies in the tropical-subtropical Atlantic induced by a reduction in the Amazon River flow in the warmer climate can, in some models, compensate for the highlatitude surface ocean freshening (Latif et al. 2000; Thorpe et al. 2001). A caveat for applying these results to past climates is that the mean state for these experiments is today's climate. In climates where meltwater from melting land ice is important, it is likely that the mean climate was much colder than today. 


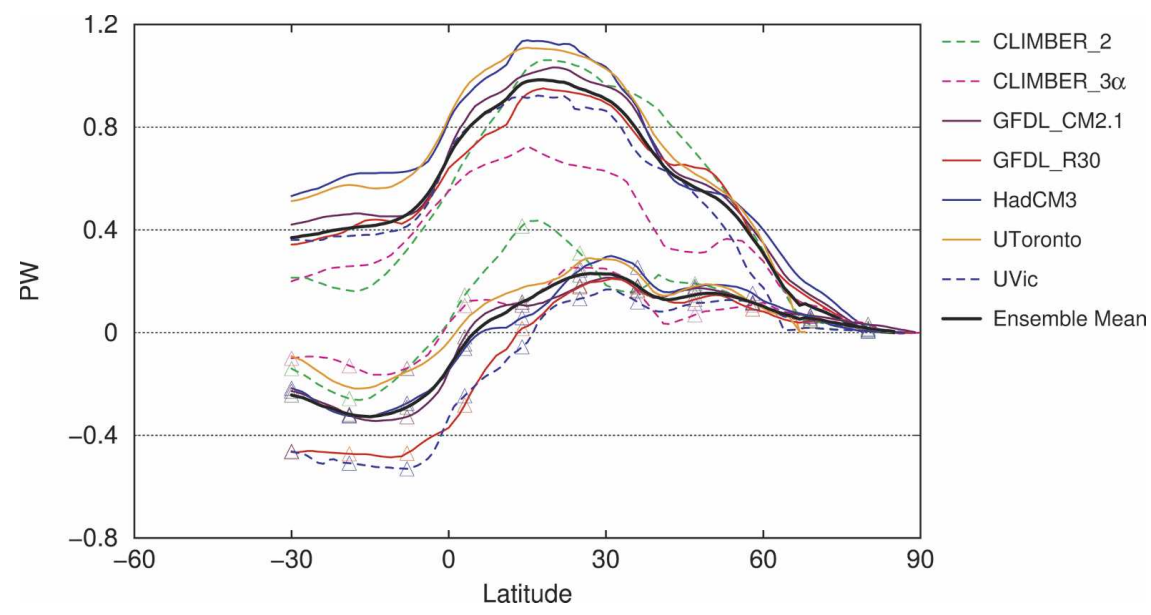

FIG. 15. Northward heat transport in the Atlantic Ocean in the 1.0-Sv water-hosing experiment (years 81 100). Lines with triangles are 1.0-Sv experiments. The others are the controls $(\mathrm{PW})$.

In contrast to the uniformly large cooling typically simulated after the shutdown of the THC, the SAT anomalies over the northern North Atlantic present more complex patterns after the slowdown of the THC. A SAT dipole, with cooling south of Greenland and warming over the Barents and Nordic Seas, is indicated by the multimodel ensemble change. Although this di- pole might be a function of the location of the hosing region, it reveals that in response to a moderate freshwater addition, the northern convection sites have an anticorrelation with the more southern convection sites in the North Atlantic. The SAT changes seen here also have this pattern. Given the rapid freshening recently observed in the Labrador Sea (Dickson et al. 2002) and

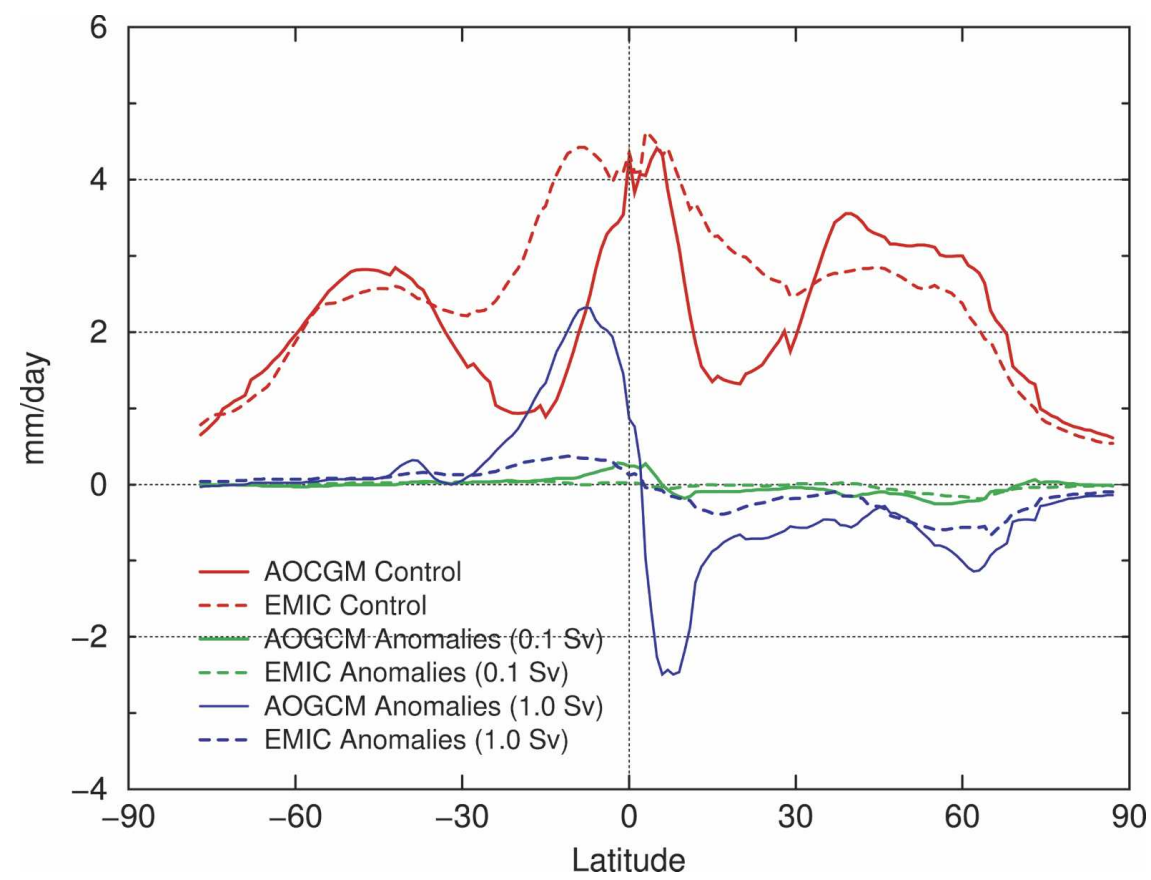

FIG. 16. The precipitation zonally averaged over the Atlantic Ocean. Red: Control precipitation; green: precipitation anomalies in the $0.1-\mathrm{Sv}$ water-hosing experiment; blue: precipitation anomalies in the $1.0-\mathrm{Sv}$ water-hosing experiment. Solid line is the AOCGM ensemble mean and dashed line is the EMIC ensemble mean. 
the reconstruction of the 8200 years before present day event, a period where the Labrador Sea deep convection was disrupted (Barber et al. 1999), this SAT change pattern provides important implications for both past and future climate changes. The maximum cooling about $3^{\circ} \mathrm{C}$ south of Greenland in response to the 0.1-Sv hosing tends to offset the $\mathrm{CO}_{2}$-induced warming in the future, so that most models simulate little surface temperature change in this area as the greenhouse gases (GHGs) increase (Cubasch et al. 2001).

The 1.0-Sv experiment is more relevant to the past abrupt climate changes. In response to 1.0-Sv freshwater perturbation, the THC weakens rapidly and almost disappears in most models. Both the northward heat and salt transports in the Atlantic Ocean reduce dramatically as the THC shuts down in this experiment. Consequently, the Northern Hemisphere cools and the Southern Hemisphere warms relative to the control integration, with the $\mathrm{NH}$ cooling being much larger than the SH warming. The simulated SAT change over the North Atlantic is comparable in magnitude to the paleoclimate reconstruction of the SAT change during the past abrupt climate changes such as the Younger Dryas event (Alley 2000).

Some models show a recovery of the THC after the elimination of the $1.0-\mathrm{Sv}$ freshwater perturbation whereas others do not. The mechanism for this different dynamical behavior of the THC is not completely understood. Possible reasons could be the following: 1) some models may not have a stable off state of the THC (Gregory et al. 2003, Romanova et al. 2004), 2) the hosing duration is too short, or 3 ) the hosing amount is too small. For the first reason, it has been shown that the effective oceanic vertical diffusivity (Manabe and Stouffer 1999b; Schmittner and Weaver 2001; Prange et al. 2003), the representation of feedback processes (Vellinga and Wood 2002; de Vries and Weber 2005), and the boundary conditions (Ganopolski and Rahmstorf 2001) are crucial factors to influence the stability of the off mode of the THC. Their different representations result in differing strengths of the nonlinearity of the THC and differing locations of the bifurcation (if it exists). Considering the potential slowdown of the THC during this century, the reversibility/irreversibility of the THC after its shutdown is an important issue for policy makers.

One of the interesting features of this study is the mixture of AOGCM and EMIC results in the same study. This allows the comparison of the EMIC model responses to the AOGCM responses given a common forcing. The EMICs used in this study can be split into three groups. In one group, the atmosphere is greatly simplified; however the other components are similar in complexity (in some cases, even more complex) to those found in the AOGCMs. The CLIMBER_3 $3 \alpha$, MIT-UWash, and UVic models are examples of this group. A second EMIC group is the models where the atmosphere is somewhat simplified and again the ocean is a general circulation model (GCM). ECBILT_CLIO is an example of this group. Finally, there are EMICs where both the atmosphere and ocean are quite simple. CLIMBER_2 is an example of this last group (Claussen et al. 2002).

Using these groupings, the EMIC's response is compared to the AOGCMs for this particular study where the forcing is applied to the ocean. For the first and second groups where the ocean component is a GCM, the oceanic responses are very similar to the AOGCMs. When the forcing is quite large $(1.0 \mathrm{~Sv})$, the atmospheric response seems different. The longitudinal SAT changes have smaller magnitude than those found in the AOGCMs. Also, the southward movement of the ITCZ was not as pronounced or sharp in these EMICs. The response of the last group using simplified atmosphere and ocean components is also quite similar to the AOGCMs. There are some noticeable differences even in the relatively small forcing case ( $0.1 \mathrm{~Sv}$; e.g., see the heat transport changes). It is unclear if those changes are statistically or physically significant. In spite of the differences noted above, it is surprising how well the EMIC responses compare to the AOGCM responses. In most of the figures presented here, the EMIC and AOGCM responses are quite similar. This result gives added confidence to the use of EMICs to study other aspects of climate.

Although many robust simulation features have been revealed, there are still clear differences and disagreements among models in simulating the THC, such as its sensitivity to freshwater addition, its multidecadal variations, and the reversibility after its shutdown. The understanding of these differences needs more detailed analyses in the future and will help further improve the ability to simulate this critical system.

Acknowledgments. We wish to thank T. Delworth, M. Harrison, and J. Russell for useful comments that improved earlier versions of this manuscript. We also thank two anonymous reviewers for their reviews, and our respective funding agencies for support.

\section{REFERENCES}

Alley, R. B., 2000: The Younger Dryas cold interval as viewed from central Greenland. Quat. Sci. Rev., 19, 213-226.

Barber, D. C., and Coauthors, 1999: Forcing of the cold events of 8200 years ago by catastrophic drainage of Laurentide lakes. Nature, 400, 344-348. 
Boyle, E. A., and L. D. Keigwin, 1987: North Atlantic thermohaline circulation during the past 20, 000 years linked to highlatitude surface temperature. Nature, 330, 35-40.

Broecker, W. S., 1997: Thermohaline circulation, the achilles heel of our climate system: Will man-made $\mathrm{CO}_{2}$ upset the current balance? Science, 278, 1582-1588.

Bryan, F., 1986: High-latitude salinity effects and interhemispheric thermohaline circulations. Nature, 323, 301-304.

Calov, R., A. Ganopolski, V. Petoukhov, M. Claussen, and R. Greve, 2002: Large-scale instabilities of the Laurentide ice sheet simulated in a fully coupled climate-system model. Geophys. Res. Lett., 29, 2216, doi:10.1029/2002GL016078.

Chappell, J., 2002: Sea level changes forced ice breakouts in the Last Glacial cycle: New results from coral terraces. Quat. Sci. Rev., 21, 1229-1240.

Cheng, W., and P. B. Rhines, 2004: Response of the overturning circulation to high-latitude freshwater perturbations in the North Atlantic. Climate Dyn., 22, 359-372.

— , R. Bleck, and C. Rooth, 2004: Multi-decadal thermohaline variability in an ocean-atmosphere general circulation model. Climate Dyn., 22, 537-590.

Chiang, J. C. H., and A. Koutavas, 2004: Tropical flip-flop connections. Nature, 432, 684-685.

Church, J. A., J. M. Gregory, P. Huybrechts, M. Kuhn, K. Lambeck, M. T. Nhuan, and P. L. Woodworth, 2001: Change in sea level. Climate Change 2001: The Scientific Basis, J. T. Houghton et al., Eds., Cambridge University Press, 640-693.

Clark, P. U., N. G. Pisias, T. F. Stocker, and A. J. Weaver, 2002: The role of the thermohaline circulation in abrupt climate change. Nature, 415, 863-869.

Clarke, G. K. C., D. W. Leverington, J. T. Teller, and A. S. Dyke, 2003: Superlakes, megafloods, and abrupt climate change. Science, 301, 922-923.

Claussen, M., and Coauthors, 2002: Earth system models of intermediate complexity: Closing the gap in the spectrum of climate system models. Climate Dyn., 18, 579-586.

Crowley, T. J., 1992: North Atlantic deep water cools the Southern Hemisphere. Paleoceanography, 7, 489-497.

Cubasch, U., and Coauthors, 2001: Projections of future climate change. Climate Change 2001: The Scientific Basis, J. T. Houghton et al., Eds., Cambridge University Press, 525-582.

Delworth, T., and K. W. Dixon, 2000: Implications of the recent trend in the Arctic/North Atlantic Oscillation for the North Atlantic thermohaline circulation. J. Climate, 13, 3721-3727.

_, S. Manabe, and R. J. Stouffer, 1993: Interdecadal oscillation of the thermohaline circulation in a coupled oceanatmosphere model. J. Climate, 6, 1993-2011.

— R. J. Stouffer, K. W. Dixon, M. J. Spelman, T. R. Knutson, A. J. Broccoli, P. J. Kushner, and R. T. Wetherald, 2002: Review of simulations of climate variability and change with the GFDL R30 coupled climate model. Climate Dyn., 19, 555574.

— models. Part I: Formulation and simulation characteristics. $J$. Climate, 19, 643-674.

de Vries, P., and S. L. Weber, 2005: The Atlantic freshwater budget as a diagnostic for the existence of a stable shut-down of the meridional overturning circulation. Geophys. Res. Lett., 32, L09606, doi:10.1029/2004GL021450.

Dickson, B., I. Yashayaev, J. Meincke, B. Turrell, S. Dye, and J. Holfort, 2002: Rapid freshening of the deep North Atlantic Ocean over the past four decades. Nature, 416, 832-837.

Dixon, K. W., T. Delworth, M. Spelman, and R. J. Stouffer, 1999:
The influence of transient surface fluxes on North Atlantic overturning in a coupled GCM climate change experiment. Geophys. Res. Lett., 26, 2749-2752.

Duplessy, J.-C., N. J. Shackleton, R. G. Fairbanks, L. Labeyrie, and D. W. Oppo, 1988: Deepwater source variations during the last climatic cycle and their impact on the global deepwater circulation. Paleoceanography, 3, 343-360.

Flato, G. M., and G. J. Boer, 2001: Warming asymmetry in climate change simulations. Geophys. Res. Lett., 28, 195-198.

Ganachaud, A., and C. Wunsch, 2000: Improved estimates of global ocean circulation, heat transport and mixing from hydrographic data. Nature, 408, 453-456.

Ganopolski, A., and S. Rahmstorf, 2001: Rapid changes of glacial climate simulated in a coupled climate model. Nature, $\mathbf{4 0 9}$, 153-158.

Gordon, C., C. Cooper, C. A. Senior, H. Banks, J. M. Gregory, T. C. Johns, J. F. B. Mitchell, and R. A. Wood, 2000: The simulation of SST, sea ice extents and ocean heat transports in a version of the Hadley Centre coupled model without flux adjustments. Climate Dyn., 16, 147-168.

Gregory, J. M., O. A. Saenko, and A. J. Weaver, 2003: The role of the Atlantic freshwater balance in the hysteresis of the meridional overturning circulation. Climate Dyn., 21, 707-717.

- and Coauthors, 2005: A model intercomparison of changes in the Atlantic thermohaline circulation in response to increasing atmospheric $\mathrm{CO}_{2}$ concentration. Geophys. Res. Lett., 32, L12703, doi:10.1029/2005GL023209.

Griffies, S. M., 2004: Fundamentals of Ocean Climate Models. Princeton University Press, 496 pp.

Hansen, B., and S. Osterhus, 2000: North Atlantic-Nordic Seas exchanges. Progress in Oceanography, Vol. 45, Pergamon, 109-208.

Jungclaus, J. H., and Coauthors, 2006: Ocean circulation and tropical variability in the coupled model ECHAM5/MPIOM. J. Climate, in press.

K-1 Model Developers, 2004: K-1 coupled model (MIROC) description. K-1 Tech. Rep. 1, H. Hasumi and S. Emori, Eds., Center for Climate System Research, University of Tokyo, 34 pp.

Kamenkovich, I., A. Sokolov, and P. Stone, 2002: An efficient climate model with a 3D ocean and statistical-dynamical atmosphere. Climate Dyn., 19, 585-598.

Kiehl, J. T., and P. R. Gent, 2004: The Community Climate System Model, version 2. J. Climate, 17, 3666-3682.

Latif, M., E. Roeckner, U. Mikolajewicz, and R. Voss, 2000: Tropical stabilization of the thermohaline circulation in a greenhouse warming simulation. J. Climate, 13, 1809-1813.

Levermann, A., A. Griesel, M. Hofmann, M. Montoya, and S. Rahmstorf, 2005: Dynamic sea level changes following changes in the thermohaline circulation. Climate Dyn., 24, 347-354.

Lohmann, G., 2003: Atmospheric and oceanic freshwater transport during weak Atlantic overturning circulation. Tellus, 55A, 438-449.

Manabe, S., and R. J. Stouffer, 1988: Two stable equilibria of a coupled ocean-atmosphere model. J. Climate, 1, 841-866.

- , and 1995: Simulation of abrupt climate change induced by freshwater input to the North Atlantic ocean. $\mathrm{Na}$ ture, 378, 165-167.

_, and _ 1999a: The role of thermohaline circulation in climate. Tellus, 51A, 91-109. 
$\longrightarrow$, and - 1999b: Are two modes of thermohaline circulation stable? Tellus, 51A, 400-411.

Mikolajewicz, U., and R. Voss, 2000: The role of the individual air-sea flux component in $\mathrm{CO}_{2}$-induced changes of the ocean's circulation and climate. Climate Dyn., 16, 627-642.

Montoya, M., A. Griesel, A. Levermann, J. Mignot, M. Hofmann, A. Ganopolski, and S. Rahmstorf, 2005: The Earth System Model of Intermediate Complexity CLIMBER-3 $\alpha$. Part I: Description and performance for present day conditions. Climate Dyn., 25, 237-263.

Otto-Bliesner, B., and E. C. Brady, 2001: Tropical Pacific variability in the NCAR Climate System Model. J. Climate, 14, 35873607.

Petoukhov, V., A. Ganopolski, V. Brovkin, M. Claussen, A. Eliseev, C. Kubatzki, and S. Rahmstorf, 2000: CLIMBER-2: A climate system model of intermediate complexity. Part I: Model description and performance for present climate. Climate Dyn., 16, 1-17.

Prange, M., G. Lohmann, and A. Paul, 2003: Influence of vertical mixing on the thermohaline hysteresis: Analyses of an OGCM. J. Phys. Oceanogr., 33, 1707-1721.

Rahmstorf, S., 1995: Bifurcations of the Atlantic thermohaline circulation in response to changes in the hydrological cycle. Nature, 378, 145-149.

- 1996: On the freshwater forcing and transport of the Atlantic thermohaline circulation. Climate Dyn., 419, 207-214.

Rind, D., P. deMenocal, G. Russell, S. Sheth, D. Collins, G. Schmidt, and J. Teller, 2001: Effects of glacial meltwater in the GISS coupled atmosphere-ocean model. J. Geophys. Res., 106, 27 335-27 353.

Romanova, V., M. Prange, and G. Lohmann, 2004: Stability of the glacial thermohaline circulation and its dependence on the background hydrological cycle. Climate Dyn., 22, 527-538.

Schiller, A., U. Mikolajewicz, and R. Voss, 1997: The stability of the North Atlantic thermohaline circulation in a coupled ocean-atmosphere general circulation model. Climate Dyn., 13, 325-347.

Schmidt, M. W., H. J. Spero, and D. W. Lea, 2004: Links between salinity variation in the Caribbean and North Atlantic thermohaline circulation. Nature, 428, 160-163.

Schmittner, A., and A. J. Weaver, 2001: Dependence of multiple climate states on ocean mixing parameters. Geophys. Res. Lett., 28, 1027-1030.

Schmitz, W. J., Jr., and M. S. McCartney, 1993: On the North Atlantic circulation. Rev. Geophys., 31, 29-50.

Stammer, D., and Coauthors, 2003: Volume, heat, and freshwater transports of the global ocean circulation 1993-2000, estimated from a general circulation model constrained by
World Ocean Circulation Experiment (WOCE) data. J. Geophys. Res., 108, 3007, doi:10.1029/2001JC001115.

Stocker, T. F., 2002: North-south connections. Science, 297, 1814 1815.

, and D. G. Wright, 1991: Rapid transitions of the ocean's deep circulation induced by changes in surface water fluxes. Nature, 351, 729-732.

- , and A. Schmittner, 1997: Influence of $\mathrm{CO}_{2}$ emission rates on the stability of the thermohaline circulation. Nature, $\mathbf{3 8 8}$, 862-865.

Stommel, H. M., 1961: Thermohaline convection with two stable regimes of flow. Tellus, 13, 224-230.

Stouffer, R. J., 2004: Time scales of climate response. J. Climate, 17, 209-217.

Thorpe, R. B., J. M. Gregory, T. C. Johns, R. A. Wood, and J. F. B. Mitchell, 2001: Mechanisms determining the Atlantic thermohaline circulation response to greenhouse gas forcing in a non-flux-adjusted coupled climate model. J. Climate, 14, 3102-3116.

Timmermann, A., M. Latif, R. Voss, and A. Groetzner, 1998 Northern Hemispheric interdecadal variability: A coupled air-sea mode. J. Climate, 11, 1906-1931.

Vellinga, M., and R. Wood, 2002: Global climatic impacts of a collapse of the Atlantic thermohaline circulation. Climate Change, 54, 251-267.

— , and P. Wu, 2004: Low-latitude freshwater influence on centennial variability of the Atlantic thermohaline circulation. $J$. Climate, 17, 4498-4511.

Weaver, A. J., and E. S. Sarachik, 1991: Evidence for decadal variability in an ocean general circulation model: An advective mechanism. Atmos.-Ocean, 29, 197-231.

_ and C. Hillaire-Marcel, 2004: Global warming and the next ice age. Science, 304, 400-402.

—_, and Coauthors, 2001: The UVic Earth system climate model: Model description, climatology and application to past, present and future climates. Atmos.-Ocean, 39, 361-428.

Wood, R. A., A. B. Keen, J. F. B. Mitchell, and J. M. Gregory, 1999: Changing spatial structure of the thermohaline circulation in response to atmospheric $\mathrm{CO}_{2}$ forcing in a climate model. Nature, 399, 572-575.

Wunsch, C., 2002: What is the Thermohaline Circulation? Science, 298, 1179-1181.

Yukimoto, S., and A. Noda, 2002: Improvements of the Meteorological Research Institute global ocean-atmosphere coupled GCM (MRI-GCM2) and its climate sensitivity. CGER's Supercomputing Activity Rep., National Institute for Environmental Studies, Tsukuba, Japan, 161 pp. 